\title{
THE EFFECTS OF FREEZING AND THAWING ON PRESTRESSED CONCRETE
}

JANUARY, 1959

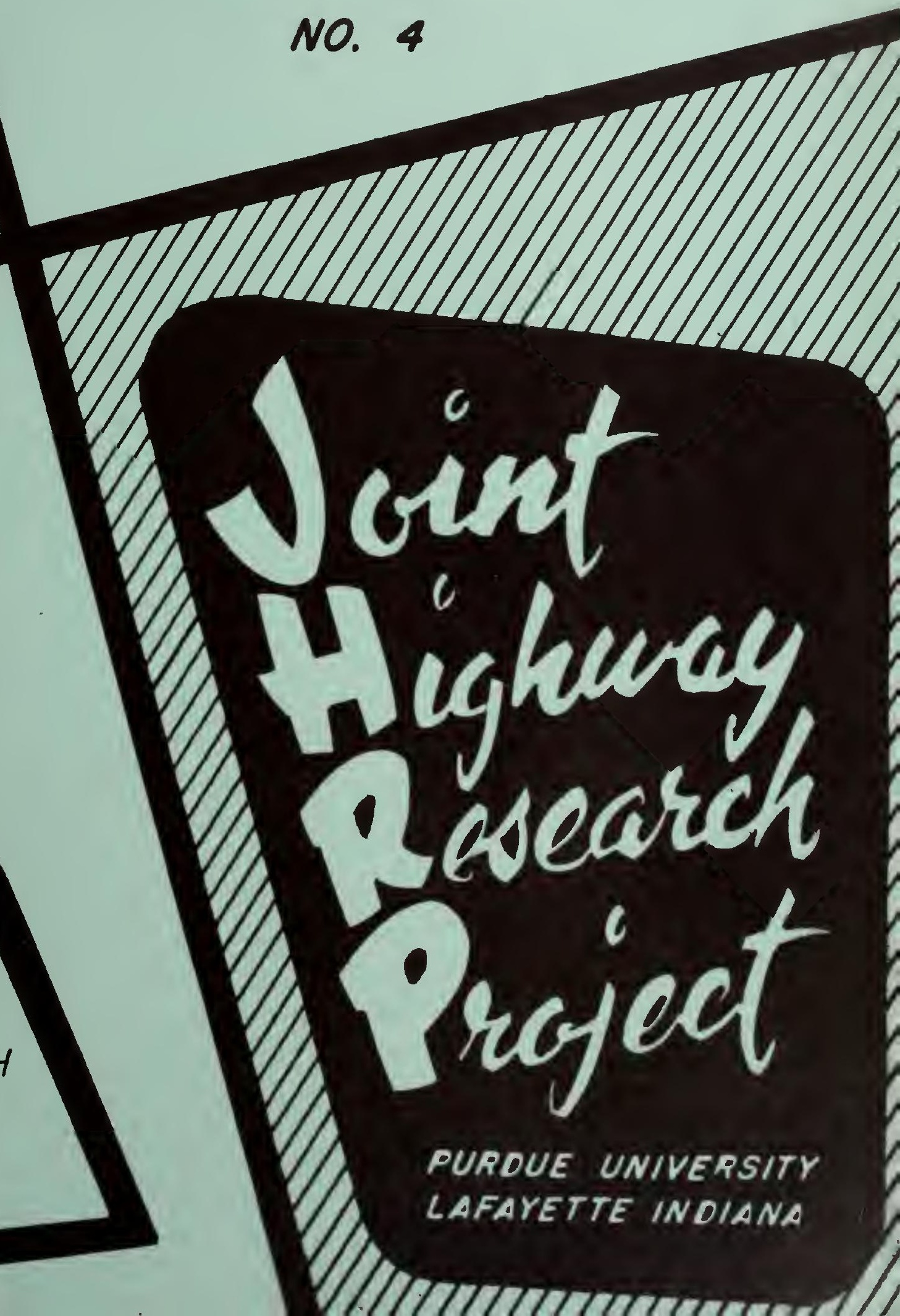


Final Roport

THE EFFECTS OF FREEZING AND THANIIIG

ON PRESTRTSSED CONCRETE

TO:

K. B. Woods, Director

Joint Highwey Research Project

January 29, 1959

Frov: $\quad$ H. L. Michael, Assistant Director

File: $5013-3$

Joint Hichway Research Frojoct

Project: $C=36-58 \mathrm{C}$

Attached is a report entit.1ed, "Ths Effects of Freezing and Thawing on Prestressed Conerete," by Fouad E. Mugleh. This report has bean prepared under the supervision of $M_{\text {. }} J$. Gutzililer and was ajso used by Mr. Wusleh as his thesis in partial fulfillnent of the requirements for the degree of Master of Seience in Civil Engineering.

It is anticipated that a paper will be prepared by Messrs. Musloh and Gutzwiller for presentation at the Annual Purdue Road School in 1959,

The report is presented for the record.

Respectfully submitted,

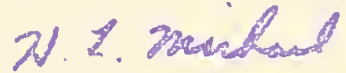

H. L. Michael, Secretery

HLY:ac

Attachment

ce: J.R. Cooper

W. L. Dolch

r. H. Goetz

J. T. Hallett

F. F. Hevey

G. A. Hawkins (H.B. Scott)

G. A. Loonards

J. F. Mclaughlin

R. D. Miles

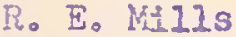

B. H. Petty

C. E. Vogelgesang

J. L. Uling

J.E. Hilson

I. J. Yoder 
Digitized by the Internet Archive in 2011 with funding from

LYRASIS members and Sloan Foundation; Indiana Department of Transportation 
Final Report

THE EFIECTS OF FREEZING AND THANTNG

ON PRESTRESSEIJ CONCRETE

by

Fouad E. Musleh, Graduato Asbistant

Jolnt Highway Kosearch Project

Project No: $\mathrm{C}=36-58 \mathrm{C}$

File No: 5-13-3

Furdue University

Lafayetie, Indians.

January 29, 1959 


\section{ACKINO ILEDGIENTS}

The author wishes to express his gratitude to the Joint Highway Research Project at Purdue University, Professor K. B. loods, Director, who sponsored this study. He is deeply appreciative of the inspiration and assistance of Professor M. J. Gutzwiller, his major professor and of Professor J. I. Waling, Professor of Structural Engineering. He is also grateful to Professor J. M. Mclaughlin for his comments and help throughout the study.

Special recognition is aue to the Stressteel Corporation for their donation of the steel and the accessories used in this study. 
TABIE OF CONTENTS

Page

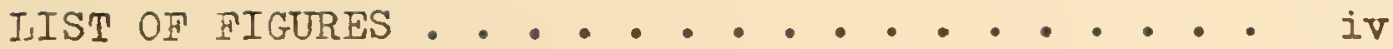

LIST OF TABLES • • • • • • • • • • • • vi vi

ABSTRACT . . . . . . . . . . . . . vii

INTRODUCTION •. . . . . . . . . . . . I

PURPCSE AND SCOPE . . . . . . . . . . . 6

MATERIAIS . . . . . . . . . . . . . 8

Coarse Aggregate . . . . . . . . . . . 8

Fine Aggregate . . . . . . . . . . . 8

Cement .................... II

Air Entraining Agent ............. . II

Water..................... . . II

Steel..................... Il

EQUIPMENT . . . . . . . . . . . . I3

Concrete Mixer . . . . . . . . . 13

Vacuum Saturating Unit .......... 13

Fydraulic Jacking Unit . . . . . . . . . . 13

Forms ................ . . 17

Freezing and Thawing Apparatus ....... 17

Natural frequency lieasing Unit . . . . . 19

RESEMRCH PROCEJURE . . . . . . . . . 21

Mix Design . . . . . . . . . . . . 21

Mixing Procedure . . . . . . . . . . 21

Molding an? Curing of Specimens . . . . . . 23

Freezing and Thawing of Specimens . . . . . 26

RESULT; AND DISCUSSION • • • . . • • • • 30

Presentation of Test Results . . . . . . 30

Types of Concrete Failure . . . . . . . . 48

Discussion of Results . . . . . . . . 52

CONCLUSIONS . . . . . . . . 59

BIBLIOGRAPHY ............. 60 
LIST OF FIGURES

Page

1. Lancaster Tub-Type Counter-Current Mixer . . I4

2. Vacuum Saturating Unit......... 15

3. Sixty-Ton Hydraulic Jacking Unit and Specimen in Position for Post-Tensioning . . 16

4. A Typical Concrete Form . . . . . . . 18

5. The Natural Frequency Apparatus ana Specimen in Position for Testing ...... . . 20

6. Slump Test Measurement . . . . . . 24

7. One-Tenth Cubic Foot Bucket--For Air Content Measurement .......... 25

8. The Effect of Freezing and Thawing on the Dynamic Modulus of Elasticity, Mix IA . . 34

9. The Effect of Freezing and Thawing on the Dynamic Modulus of Elasticity, Mix IB . . 35

10. The Effect of Freezing and Thawing on the Dynamic Modulus of Elasticity, Mix IC . . 36

11. The Effect of Freezing and Thawing on the Dynamic Modulus of Elasticity, Nix IIA . . 37

12. The Effect of Freezing and Thawing on the Dynarnic Modulus of Elasticity, Mix IIB. . 38

13. The Effect of Freezing and Thawing on the Dynamic Iodulus of Elasticity, Mix IIC . . 39

14. The Effect of Preezing and Thawing on the Dynamic Modulus of Elasticity, Mix IA . . 40

15. The Effect of Freezing and Thawing on the Dynamic Modulus of Elasticity, Mix IB . . 41

16. The Effect of Freezing and Thawing on the Dynamic lodulus of Elasticity, liix IC • . . 42

17. The Effect of Freezing and Thawing on the Dynamic Modulus of Blasticity, Mix IIA . . 
Page

18. The Effect of Freezing and Thawing on the Dynamic Modulus of Elasticity, Mix IIB . • 44

19. The Effect of Freezing and Thawing on the Dynamic Modulus of Elasticity, Mix IIC . . 45

20. The Effect of Freezing and Thawing on the Dynamic Modulus of Elasticity, Series I • 46

21. The Effect of Freezing and Thawing on the Dynamic Modulus of Elasticity, Series II • 47

22. A Typical Failure of a Post-Tensioned Beam . 51

23. Three Mypes of Failure of Concrete Caused by Deleterious Material......... 53 


\section{LIST OF TABLES}

Page

1. Characteristics of Coarse Aggregate (2049) - 9

2. Characteristics of Fine Aggregate (79-1) . . 10

3. Characteristics of Stressteel Bars . . . . 12

4. Mix Design Data . . . . . . . . 22

5. Specimens Markings and Test Summary . • . 27

6. Durability Factors of Series I Beams at 300 Cycles . . . . . . . 49

7. Durability Factors of Series II Beams at 300 Cycles . . . . . . . . 50 


\section{ABSTRACT}

Musleh, Fouad Elyas, M.S.C.ฐ., Purdue University January, 1959. The Effect of Freezing and Tha"ing on Prestressed Concrete. Major Professor: M. J. Gutzwiller. An experiment was made with the following objectives:

1. To study the durability of prestressed concrete under repeated cycles of freezing and thawing.

2. To compare the freezing and tharing effects on prestressed concrete and ordinary concrete for specimens made of the same mix giving an ultimate strength of 5000 psi or better after 28 days.

3. To compare the effect of freezing and thawing on prestressed concrete having an ultimate strength of 5000 psi and ordinary concrete specimens made with a leaner mix giving an ultimate strength of about 3000 psi after 28 days.

In all, 48 concrete-beam specimens were made from 8 mixes. Six mixes produced specimens having a minimum ultimate compressive strength of $5000 \mathrm{psi}$, while two mixes gave specimens having a minimum ultimate strength of 3000 psi. Freeze-thaw deterioration graphs are show for the individual beams and for the averages of similar beams. Tables for durability factors of individual beams, as well as the average durability factor for similar beams, are presented. 
Significant improvement in the durability was found to result from post-tensioning of the beams. Post-tensioned concrete specimens made of a rich mix showed better durability than unstressed concrete made of the same mix and also better than unstressed concrete made of a leaner $\operatorname{mix}$.

Within the scope of this experiment it was observed that ungtressed concrete made of the leaner mix was more durable than unstressed concrete made of the richer mix. 


\section{INTRODUTTION}

In the United States the use of prestressed concrete has now developed to such a stage that detailed irformation concerning its physical characteristics is urgently needed by engineers.

Prestressed concrete has many new and important applications in Civil and Structural Engineering and offers many advantages. The fine cracks that develop in conventional concrete cannot be aroided. With prestressed concrete the ahsence of cracks as a permanent feature can be assured up to a maximum loading. The flexibility and resilience of a prestressed concrete stmucture are also matters of great practical importance. Prestressed concrete members of lesser depths than these required in ordinary reinforced concrete may be employed. mhis, of course, means a saving in the volume of concrete to be used in a given stmucture, in addition to the savings in the weight of steel which results from the use of high strength steel bars or wires.

The striking difference in the cost ratio of materials to labor in the United States as compared to some European countries has influenced the direction of the development of this new art. European countries have taken the lead in the use of prestressed concrete on a wide scale. Yet, there is little doubt that prestressed concrete will eventually replace many of the ordinary reinforced concrete structures. 
With the birth of this new era of prestressed concrete a new field has been opened for research to study the physical characteristics of this new combination of materials. Inny of the qualities of prestressed concrete have been investigated, yet $i \tau$ is believed that the following research work is one of the first to attempt to study the durability of prestressed concrete.

The effect of freezing and thawing on ordinary concrete has been investigated. Woods and Lewis $(1)^{*}$ reported that the effect of freezing and thawing on some materials in a highly-saturated state is a primary factor in their lack of durability in concrete. The absorption and pore or void characteristic of the materials determine their susceptibility to this type of damage. They also reported that the curability of concrete could be improved by drying the aggregates before the incorporation in the concrete and by the use of air entrainment. They recommended these two factors to improve the durability of concrete made of inferior aggregates. Bartel (2) recommended the use of air entrainment to improve the durability of concrete made with poor fine aggregates. He also found that vacurum saturation of agsregates makes them particularly vulnerable to attack by freezing and thaving. He also found that the richer mixes are likely to be less resistant to freezing and thawing than the leaner ones.

* Numbers in parentheses refer to references appended to this paper. 
Pendley (3) used deformed steel bars in the concrete for his experiments on freezing and thawing and allowed a bond to develop between the bars and the concrete. He also employed a steel restraining device around the beam and subjected the beam to a compressive load of 500 psi. Although his arrangement did not directly invclve prestressing (or post-tensioning) of concrete and the freezethaw cycle was between -18 degrees and 135 degrees F, his results shed some light on this research work. He found that:

1. Restraint of concrete decreased deterioration in freezing and thawing. The greatest improvements in durability were obtained with the aggregates having the poorest durability without restraint.

2. Neither the presence of nor the amount of steel reinforcement affected the durability of the concrete si.gnificant,ly •

3. The increase in durability of restrained bears was apparently due to the prevention of cracking perpendicular to the longitudinal axis of the beam. The crack pattern in restrained beams was parallel to the beam axis as compared to a random patterm in unrestrained beams.

Higgs (4) reported that in concrete containing a durable coarse aggregate and with an air content of above 2.5 percent, the influence of fine aggregates on the durabjlity of concrete is negligible. This result was a?so 
reported by Valker and Bloem (5) in their studies.

Jackson (6) reported that the durability of concrete subjected to freezing and thawing decreases as the water cement ratio increases. This same result was reported by Hansen ( 7 ).

The most acceptable explonation of concrete failure under repeated cycles of freezing and thawing was the hypothesis presented by T. C. Powers (8). This hypothesis presents the action of frost as being the cause of producing hydraulic pressure which tends to cause the deterioration of concrete. I'his hydraulic pressure depends on many factors, the most important of which is the permeability of the material through which the water must flow to escape from the saturated regions on the surface of a test specimen during the cooling cycle. The degree of saturation and the absorptivity of the test specimens were emphasized as important factors in discussing freezing and thawing of concrete.

Confining our consideration to the cement paste, we know that the freezing and thawing damage is related:

1. Directly to the degree of saturation

2. Directly to the bubble spacing factor

3. Inversely to the tensile streneth

4. Inversely to the permeability

At the present time there is no universally accepted specification for the determination of deterioration characteristics of prestressed concrete. The ASTH specification 
C-291-52T, "Method of Test for Resistance of Concrete Specimens to Rapid Freezing in Air and Thawing in Water or Brine," was used as a guide in the execution of this research. 


\section{PURPOSE AND SCOPE}

The purvose of this research was:

1. To study the durability of prestressed concrete under repeated cycles of freezing and thawing.

2. To compare the freezing and thawing effects on prestressed concrete and ordinary concrete for specimens made of the same mix giving an ultimate strength of 5000 psi or better after 28 days.

3. To compare the effect of freezing and thawing on prestressed concrete having an ultimate strength of 5000 psi and ordinary concrete specimens made with a leaner mix giving an ultimate strength of about 3000 psi after 28 days.

The freezing and thawing machine available could accommodate a reasonable number of beams as large as 3 in. $\mathrm{x} 4$ in. $\mathrm{x} 16$ in. A post-tensioning arrangement was used in orier to develop the desired force throughout the full length of the prestressed simecis.

Two series of tests were conducted in this study. Two different mix designs were included in each series. One mix lesign was used for three batches and the other for one batch. Six $3 \times 4 \times 16$-inch beams (and $6 \times 12$-inch compression test cylinders) were made from each batch of concrete, resulting in twenty-four beams for each series. The results of freezing and thawing tests on a total of 48 beams are thus reported in this thesis.

Series I and II were identical in all respects except 
the time of curing. Series I was cured for 28 days and series II was cured for 14 days. In each series, mix designs $A, B$ and $C$ were the same and were intended to have a minimum ultimate compressive strength of 5000 osi. nix design $D$ in each series was intended to have a minimum ultimate compressive strength of 3000 nsi. 


\section{MATERIAIS}

\section{Coarse Asgregate}

The coarse asgregate (materlal retained on a No. 4 sieve) used in this investigation was processed in the Jolnt Highway Research Laboratory. The gravel as obtained met the specifications of the State Highway Department of Indiano for slze number 5. The laboratory deslgnation for this asgregate is 2049. The gravel was brought into the laboratory and soparated into four gradations: I in. to $3 / 4 \mathrm{in.}, 3 / 4 \mathrm{in}$. to $1 / 2 \mathrm{in.,} 1 / 2$ to $3 / 8 \mathrm{in.}$ and $3 / 8 \mathrm{in}$. to No. 4. All matorial retained on the I-inch sleve was digcarded. The resulting gradation and the physical properties of the coarse aberegate are shoin in Table 1.

\section{Fine Argrerate}

The Ine aggregate (naterial passing the No. 4 sieve) was local sand (Iaboratory designation 79-1) obtalned from a river terrace deposit. This material met the specificatlons of the State Hichway Dopartment of Indiana for cradation 14, number 2. This sand vad divided into two parts--that passing a No. 16 slove and thot retained on a No. 16 sieve. The physical properties of this sand and the gradation used in this study are shown in Table 2. 
Table 1

CHARACTERISTICS OF COARSE AGGREGATE (2049)

Dry Rodded Unit Weight

Bulk Specific Gravity

Absorption

Gradation of Coarse Aggregates

Size

No. \& to $3 / 8$ in.

$3 / 8$ in. to $1 / 2 \mathrm{in.}$

$1 / 2 \mathrm{in.}$ to $3 / 4 \mathrm{in}$.

$3 / 4$ in. to 1 in.
108.8 Ibs./cu.ft.

$2.64 *$

$1.14 \% *$

Percent

25

25

25

25

* Previously established laboratory value. 


\section{Table 2}

CHARACTERISTICS OP FINE AGGREGATE (79-1)

Bulk Specific Gravity

Absorption

Fineness Modulus

Gradation of Fine Aggregate
$2.6 I^{*}$

$1.65 \%$

3.32
Size

Passing Sieve No. 16

Retained on Sieve No. 15
Percent

66

34

* Previously established laboratory value. 


\section{Cement,}

Type $I$ portland cement manufactured in central Indiana and from a single clinker batch (laboratory desigration 315) was used in all mixes.

\section{Air Entraining Agent}

Darex was used as an air entraining agent in all mixes. It was diluted, one part Darex to 9 parts water, before being used. Fifty-fire cubic centimeters of the diluted agent was used with each cubic foot of concrete.

\section{.Jater}

The mixing water was taken directly from the l.ccal water supply. The temperature of this mixing water was somewhat below room temperature when added to the concrete $\operatorname{mix}$.

\section{Steel}

The post-tensioning bars were $5 / 8$-inch round steel bars furnished by Stressteel Corporation. The physical properties of the bars are show in Table 3. Fnd plates and nuts furnished by Stressteel Corporation were used on each post-tensioned beam. 


\section{Table 3}

\section{CHARACTERISTICS OF STRESSTEEI BARS *}

Diameter in Inches

Original Area in So. Inches

Yield Strength for $0.2 \%$ offset

Yield Strength for $0.2 \%$ offset

Naximum Ioad

Tensile Strength

Modulus of Elasticity

Proportional Iimit

Rockwell Hardness Number

Chemical Analysis

Element

Carbon

Nlanganese

Phosphorus

Sulfur

Silicon
0.650

0.3254

45,750 pounds

140,600 psi

52,400 pounds

161,000 psi

$26,400,000$ psi

76,800 posi

28

Percent

$0.58 \%$

$0.82 \%$

$0.023 \%$

$0.028 \%$

$2.09,3$

- This information was furnished by the Pittsburgh resting Laboratory and was sent with the steel order. 


\section{EQUIFNEITT}

The equipment used in this study was available in the Joint Highway Reserrch Iaboratory and the Purdue University liaterials resting and Structural Engineering Laboratories. Brief descriptions of the equipment are given below.

\section{Concrete inixer}

The concrete was mixed in a Iancaster 1.5-cu.ft. tub-type counter current mixer, powered by a three-horsepower electric motor. The mixer is show in Figure 1.

\section{Vacuum Saturating Unit}

A vacuum saturating unit was used. The unit is capable of vacuum saturating $1.9 \mathrm{cu} .1 \mathrm{t}$. under an absolute pressure of $3 \mathrm{cr}$. of mercury. The unit is shown in Figure 2.

\section{Hydraulic Jacking Unit}

A new 60-ton capacity Simplex hyäraulic jack with 3 inches of travel was used in the post-tensionjing of the beams. The jack had a certified gage calibration furnished by Stressteel Corporation. The calibration of the prestressing unit was checked by use of the 120,000 pound Baldwin Universal Testing Irachine in the Purdue University Stmetural Iaboratory to assure the application of the desired magnitude of prestressing force on the beams. With this check on the calibration it was founa unnecessary to use strain gages on the bars for load checks. The jacking unit in operation is shown in Figure 3. 


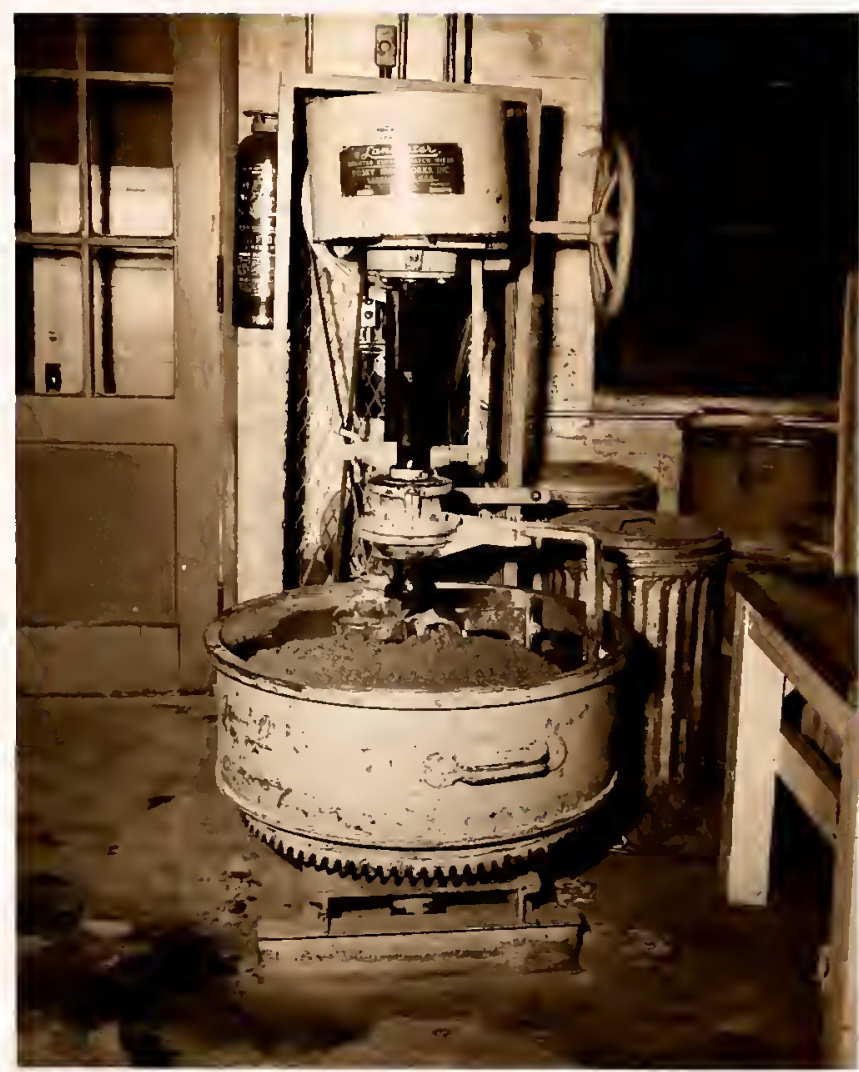

FIGURE 1 IUNCASTER TUB-TYPE COUNTER CURRENT MIXER 


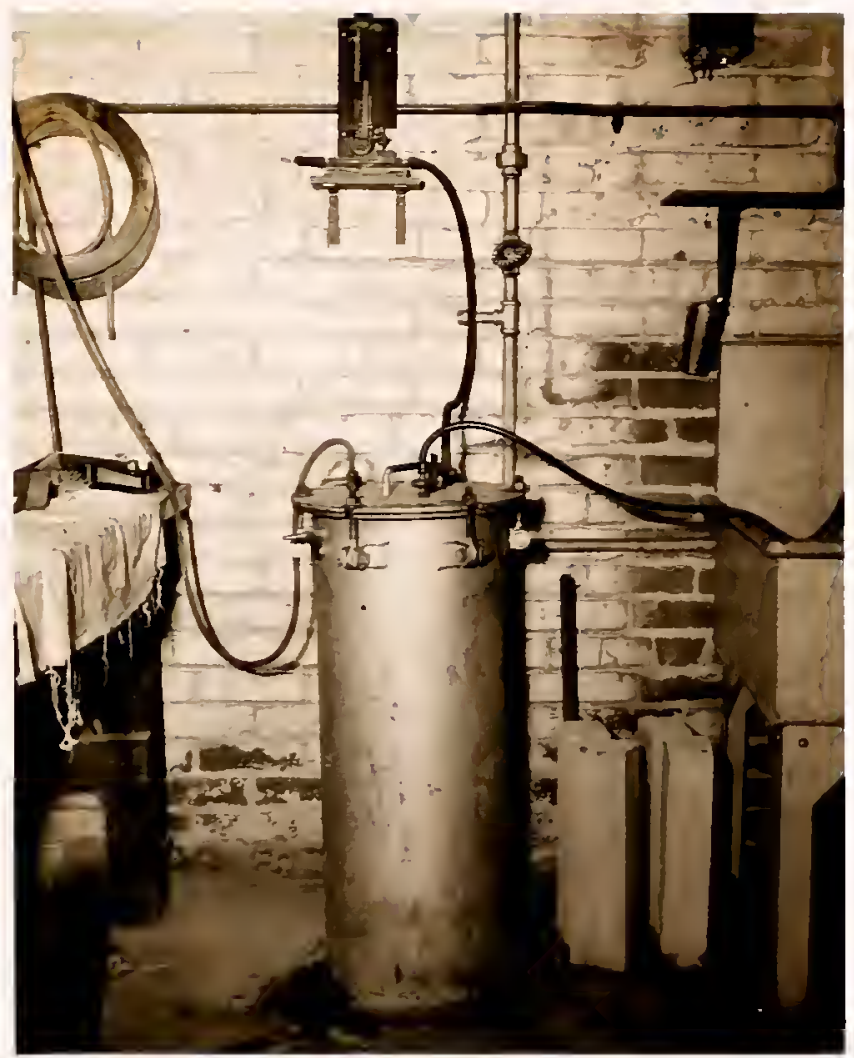

FIGURE 2 VACUUM SATURATING UNIT 


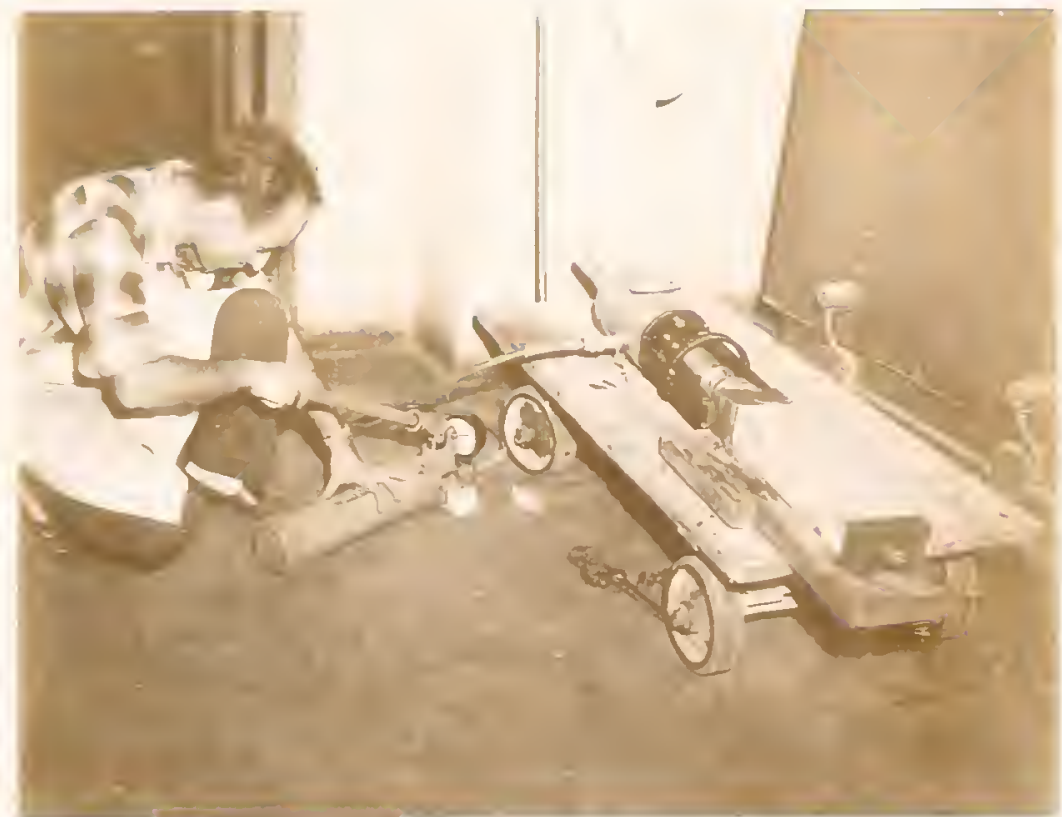

FIGURE 3 SIXTY-TON HYDRAULIC JACKING UNIT AND SPECIMEN IN POSITION FOR POST-TENSIONING 


\section{Forms}

The steel forms, normally used for 3 in. $x 4$ in. x 16 in-freeze-thaw specimens, were used in this study with some minor alterations. New sliding end plates vere prepared vith 11/16-1n. holes drilled in their centers. Two "C" clamps vere used on the ends of the forms to assure the proper dimensions of the beams. The molds were covered with a light film of 011 before the concrete was placed. The Stressteel bars were placed through the holes in the end plates and were coated with a lubricant to prevent the development of bond between the steel and the concrete. A typlcal form used to mold the beams is shom in Figure 4.

\section{Freezing and Thewins Apparaws}

In this study automatic freezing and thawins equipinent, which had been manufactured and installed by the Carrier Division of the United Clay Products Corporation, was used. Twenty-five beang can be tested in each of two compartments which serve altemately as freezing chambers and thawins tanks. Refrigeration is accomplished through colls mounted around the perimeter of the two compartments, while two fans mounted above the specimons maintain uniform air temperature In the freezing chamber. A constant 40 degree $F$. temperature of the water in the storage tank is accornplished by the use of immersion heaters. Starting with the end of the thaw cycle, the temperature is reduced to o degrees F. in about one hour. The temperature is malntained at 0 degrees $F$. for two and one-half hours to allow the centers of the beams to cool to that temperature. The thaw water is then circulated, 


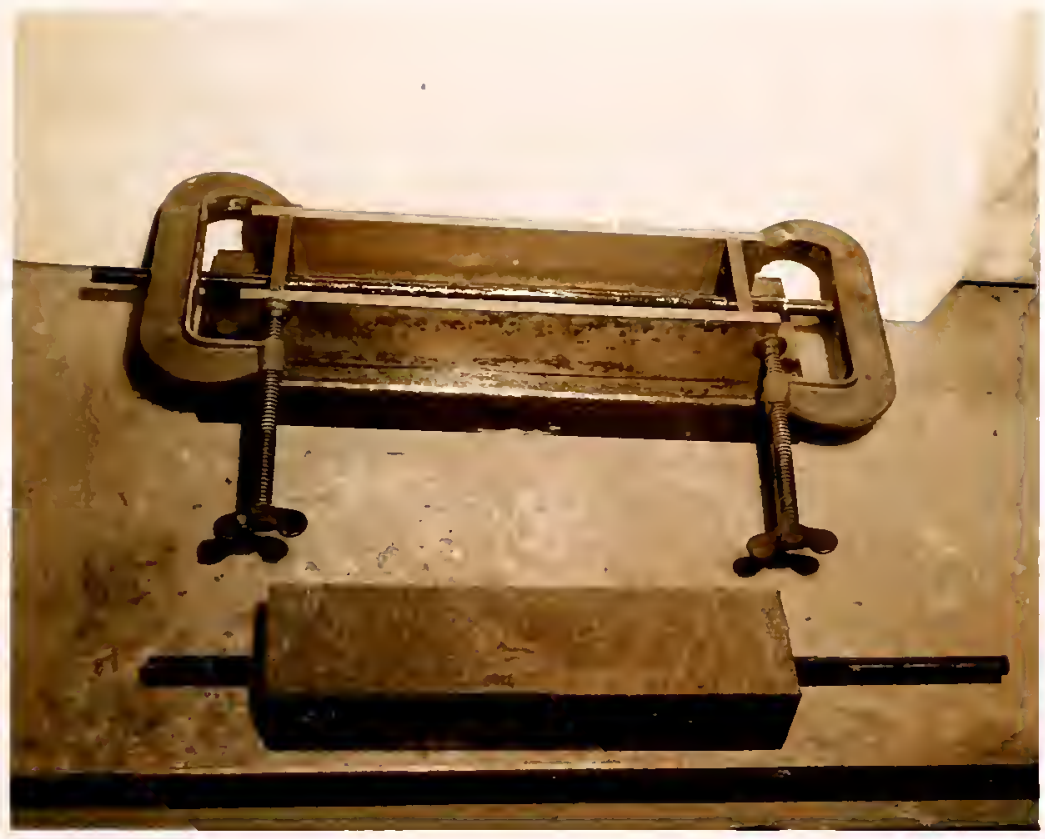

FIGURE 4 A TYPICAL CONCRETE TORM 
and the temperature is raised quickly to 40 degrees $F$. The temperature at the centers of the beams reaches 40 degrees $F$. within 30 minutes arter which the water is pumped out in about five minutes. The apparatus thus subjected the specimens to about seven cycles every 24 hours. The timing of each cycle was in agreenent with ASTI Specification C 291-52T. Trice each woek or at intervals of about 20 cycles, the apparatus was tumed off at the end of a thawing cycle to permit the velshing of the specimens and their testing to detemine the dynamic modulus of elasticity.

\section{Natural Frequency Heasuring Unit}

The natural frequency measuring unit used in these experiments is composed of a variable-frequency oscillator, a varlable-irequency driving unit to induce vibrations in the specimen at controlled frecuencles, a crystal piclup to detect the frequencles, and a milianmeter to neasure the current flow fron the pickup. When the induced vibration is of the same frequency as the natural frequency of the beam, resonance occurs and is detected by a sudden increase in the milliammeter readins. Thus, the maximum current flow occurs at the fundamental frequency of vibration of the specimen. The frequency of the induced vibration can be read directly from the oscillator dial. This fundamental frequency measuring unit, which satisfies $\Lambda$ STM Bpecification C 215-55T, "Method of Test for Iundamental Transverse, Longitudinal, and Torslonal Frequencies of Concrete Specimens," is show in Figure 5 . 


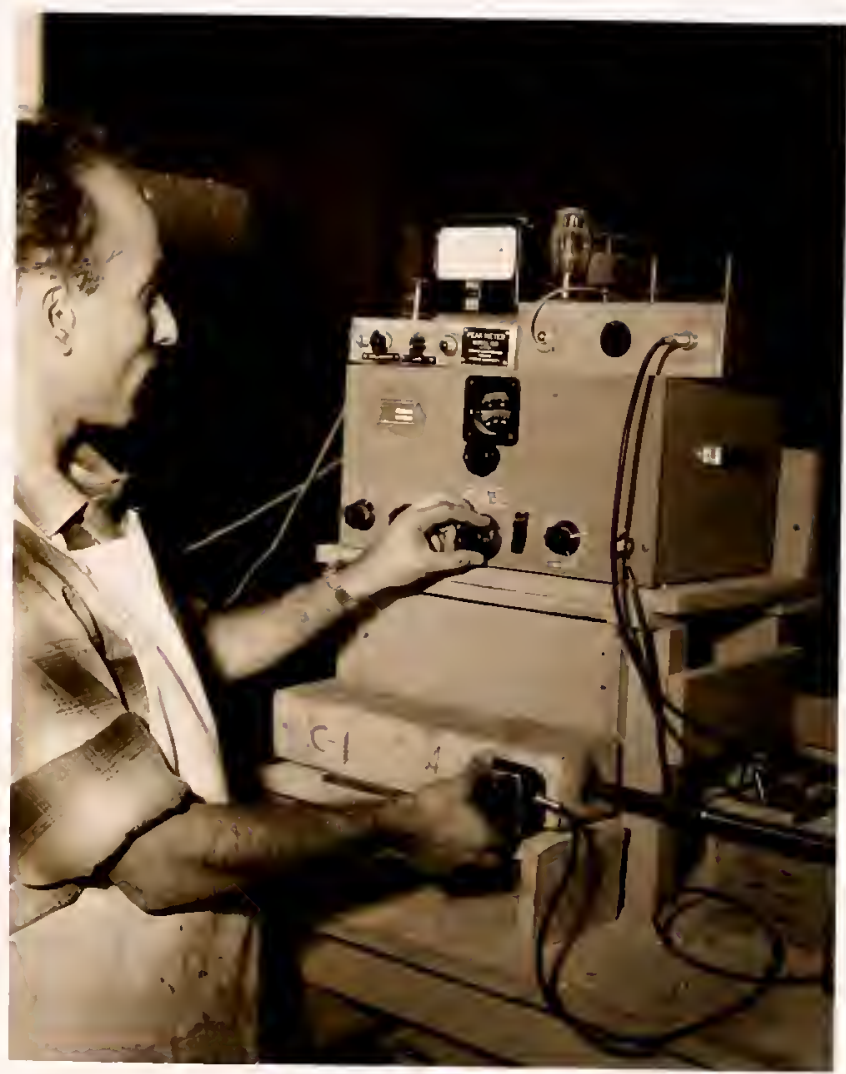

FIGURE 5 TE NATURAI FREQUENCY

APPARATUS AND SFECIMEN

IN POSITION FOR TESTING 


\section{Irix Design}

The concrete mixes were designed by the b/bo method (9), which is, in essence, the same as the "recomnended Practice for Selecting Proportions for Concrete" published by the American soncrete Institute (IO). Inix designs A, B and $\checkmark$ were tire same and were designed for a 5000-psi strength after 28 days. Iix D was designed for a strength of 3000 psi after 28 days. A four-percent air content was intended for each mix. Each mix was proportioned to give 1.5 cu.ft. of concrete. Trial mixes were used to establish workable concrete of the required strength. Detailea information concerning the mixes is show in Table 4 .

\section{Hixing Procedure}

The coarse asgregate in room-dry condition was weighed and batched 24 hours before mixine time. The aggregate was vacuum saturated and left under a constant absclute pressure of $3 \mathrm{~cm}$. of mercury until mixing time.

The fine aggre ate was weighed and batched in roomdry condition 24 hours before mixing and was saturated by the adiition of water.

The excess water in the coarse and fine aggregates was determined imediately before mixing time by weighing the aggregates when saturated and ceducting the original dry weight. This excess vater was then deducted from the 
Table 4

\section{IIX TESIGI DATA}

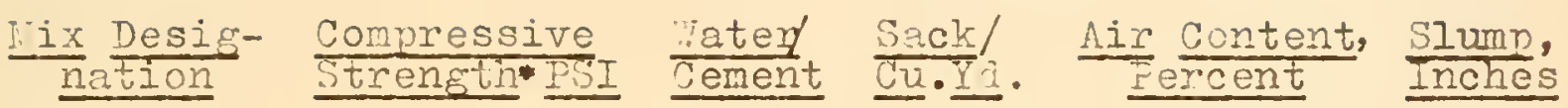

$\begin{array}{llllll}I A & 6420 & .450 & 6.76 & 2.5 & 2.5 \\ I B & 5540 & .457 & 6.74 & 2.7 & 3.5 \\ I C & 5110 & .514 & 5.61 & 2.3 & 5.5 \\ I D & 3750 & .695 & 4.36 & 1.7 & 2.5 \\ I I A & 7000 & .420 & 6.77 & 2.5 & 1.8 \\ I I B & 5600 & .445 & 6.74 & 2.0 & 3.0 \\ I I C & 5800 & .452 & 6.69 & 2.5 & 3.8 \\ \text { IID } & 3730 & .622 & 4.24 & 5.25 & 3.0\end{array}$

- Standard 6 in. by 12 in. cylinders--28 days.

Note: All mixes were designed initially by the $\mathrm{b} /$ bo method. 
water required by the mix design to determine the required mixing water. The mixing water was made up of two parts-one part includer the air entrining agent, the other part was the adjitional vater requirea to give a slump of two to four inches. The sequence of operations was as follows:

1. The coarse and fine aggregates were placel in the mixing irum and were mixed for one minute.

2. The reauired cement was weighed and added to the mixer and allowed to mix with the aggregates for another minute.

3. The water containing the air entraining a jent was added; then the additional water was poured slowly until a sufficient amount mas added to obtain 22 to 4inch slump. The mixer was allowed to rotate for ut leust two minutes, making the total minimum mixing time four minutes.

4. The slump was determined as show in pigrue 6 in accortance with Astri Designation C 143-52.

5. A gravimetric test :as perfomea to detemine the air content. This test was maje in accordance with the ASTi Designation , 138-44, except that a 1/10 cubic foot measure was used. This can be seen on Figure 7 .

6. The concrete used in the slump and gravimetric tests was discarded.

Tolaing and curing of Specimens

Tach mix provided enough concrete for three $6 \times 12-$ 


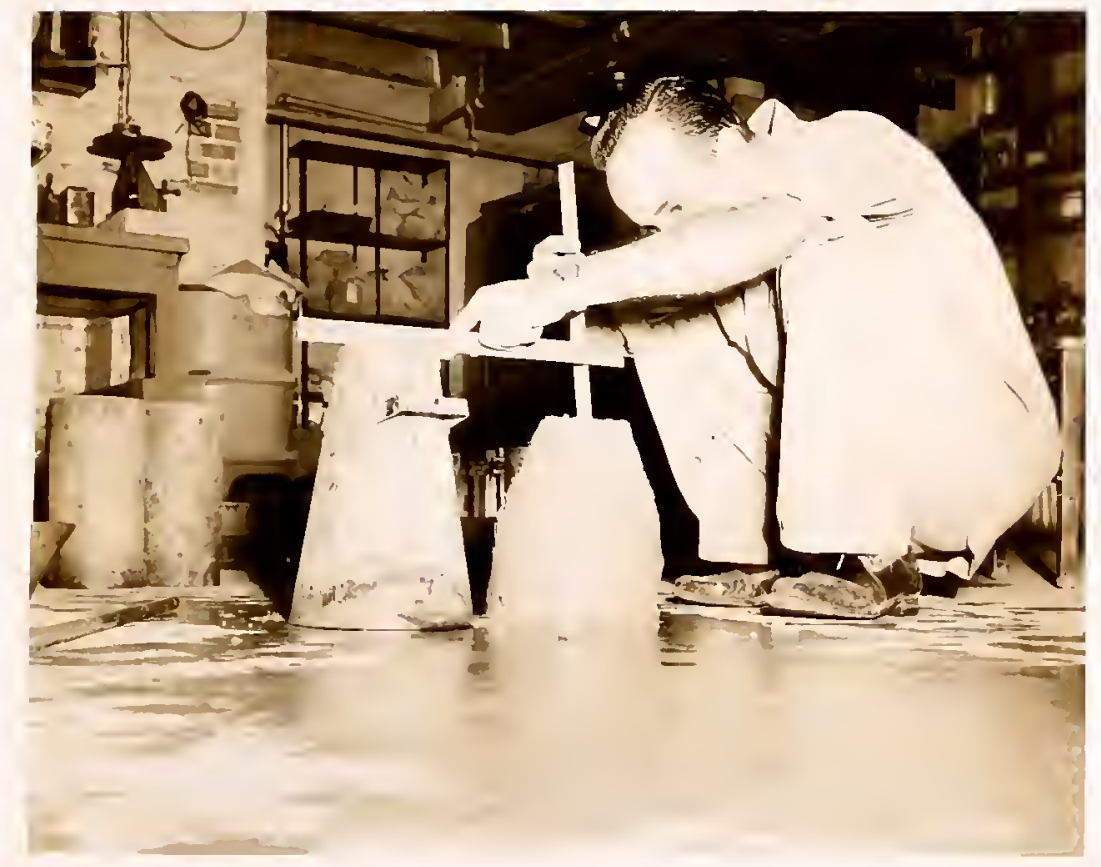

FIGURE 6 SLUMP TEST MEASUREMENT 


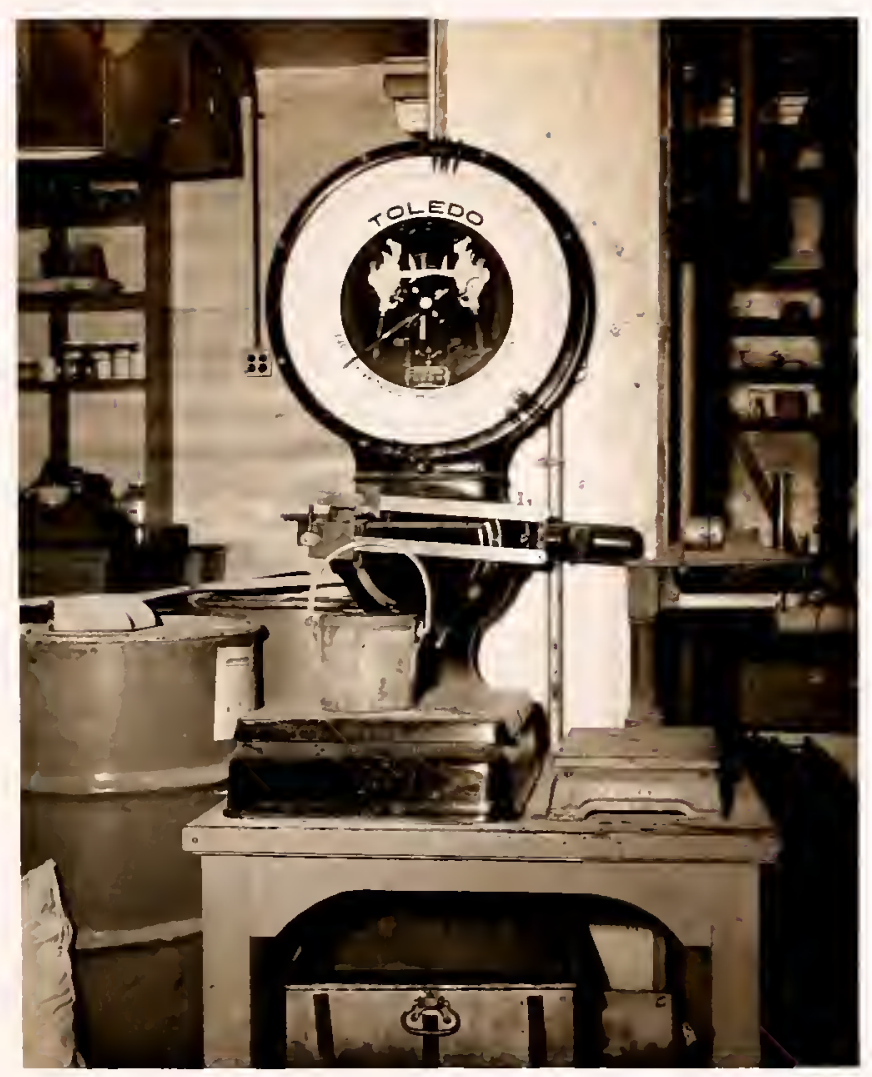

FIGURE 7 ONE-TENTH CUBIC FOOT BUCKET--FOR AIR CONTENT MEASUREMENT 
inch compression test cylinders and six $3 \times 4 \times 16$-inch beams. The fresh concrete was placed in the molds in two layers and each layer was rodded 25 times. A trowel was then passed twice along each side and end of the mold. The mold was then tapped lightly 12 times on each side and 5 times at the ends with a wooden mallet. The surface was then finished with a moistened wooden float.

The molds were covered with a damp cloth in such a way that nothing touched the exposed top of the beam or the cylinders. Heavy canvas was used to cover the cloth in order to assure a humid atmosphere for curing for 24 hours. The beams of Series I and II were then removed from the molas and were stored for 27 or 13 days respectively in a saturated lime solution at about 70 degrees $\mathrm{F}$.

The test cylinders vrere capped at 24 hours after casting time and were allowe: 24 ditional hours before they were taken out of the molds and stored in a humia room at 100 percent humidity for an additional 26 days. They were then tested.

\section{Treezing and Thawing of Specimens}

At the end of the assigned curing time the specimens were removed from the lime solution, washed, dried and weighed. They were assigned and marked with a letter-number desination as show in Table 5 .

All specimens designated by letters A, B OI C followed by numbers 1 or 2 vere tested for the fundemental frequency, 
Table 5

SPICIPER MARKINOS AID TEUT SURARY

\begin{tabular}{|c|c|c|c|}
\hline $\begin{array}{l}3000 \text { FSI } \\
\text { CONCRETE }\end{array}$ & & 000 PSI CONCRETE & \\
\hline \multirow[t]{4}{*}{$\begin{array}{c}\text { Plain Concrete } \\
\text { Steel Bar in } \\
\text { Center }\end{array}$} & $\begin{array}{c}\text { Plain concrete } \\
\text { Stecl Bar in } \\
\text { Center }\end{array}$ & $\begin{array}{l}\text { Irestressing } \\
\text { Porce Heleased } \\
\text { During Testing }\end{array}$ & $\begin{array}{l}\text { Permanently } \\
\text { restressed } \\
\text { Concrete }\end{array}$ \\
\hline & $\mathrm{Al}$ & $\begin{array}{l}\text { A3 } \\
\text { A4 }\end{array}$ & $\begin{array}{l}A 5 \\
A 6\end{array}$ \\
\hline & $\begin{array}{l}B 1 \\
B 2\end{array}$ & $\begin{array}{l}\text { B3 } \\
\text { B4 }\end{array}$ & $\begin{array}{l}35 \\
B 6\end{array}$ \\
\hline & $\begin{array}{l}\mathrm{Cl} \\
\mathrm{C} 2\end{array}$ & $\begin{array}{l}\text { C3 } \\
\text { C4 }\end{array}$ & $\begin{array}{l}35 \\
06\end{array}$ \\
\hline $\begin{array}{l}\text { D1 } \\
\text { D2 } \\
\text { D3 } \\
\text { D4 } \\
\text { D5 } \\
\text { D6 }\end{array}$ & & & \\
\hline 6 & 6 & 6 & 6. \\
\hline
\end{tabular}


which corresponded to the zero cycle and 100 percent relative modulus of elasticity. These specimens were meant to represent an ordinary concrete beam made from a rich mix. There was a total of six of these beams for each of the two series. The beams were tested for fundamental irecuency about every 20 freeze-thaw cycles and were weighed. Wach beam had a steel bar in its center.

All specimens designated by letters A, B or C followed by numbers 3 or 4 were tested for fundamental frequency and were weighed, thus giving zero cycle readings. Then these beans were post-tensioned with a net average stress of 2000 psi on the cross-sectional area. This is the recommended value of . $41^{\prime} \mathrm{c}$ used in design pructice in accordince ::ith Tentative Zecomendations for Prestressed Concrete by ACI-ASCE Joint Comittee 323 (II). These beams were put in the freezing and thawing machine. The posttensioning force was rele ssed each time before the beam was weigh and tested for fundmental frequency. The original post-tensioning force was re-applied before the beam was put back into the freezing und thawing apparatus. The beams were testea about every 20 cycles.

Specimens designateá by letters A, B or C followed by numbers 5 or 6 were post-tensioned to 2000 psi before any readings were taken. This force was left on the beams throughout the entire test period. After the initial force was apolied these beams wers weighed and tested for the 
fundamental transverse frequency. They were tested periodically about every 20 cycles.

The six beams designated by lettex $D$ and numbers

1 through 6 represented concrete made of a leaner mix for comparison purposes. To accomplish this, the beams were cast with a steel bar in the center similar to the other specimens. They were tested periodically for weight and fundamental transverse frecuency at about each 20 cycles of freezing and thawing.

The marking and the tests sumrarized in Table 5 were duplicated in Series II. 


\section{Presentation of Test Results}

The number of cycles of freezing ind thaving and the corresponing fundamental trinsverse frequency of ewch specimen rere sbtained and recorded during the experiments.

The fundamental transverse fre uency is rel ted to the modulus of elasticity by the formula ASTP C215.55 I, "ethod of Test for Tunement Trinsverse, Iongituảinl, and Torsional Frenuencies of Concrete Specimens":

$$
I=O \pi n^{2}
$$

where

$$
\begin{aligned}
\mathrm{E}= & \text { Young's modurus of elasticity in pounds per } \\
& \text { square inch } \\
\mathrm{W}= & \text { ieight of specimen in pounds } \\
n= & \text { Pundianental pransverse frequency in cycles per } \\
& \text { second }
\end{aligned}
$$

$\operatorname{anc} \overline{\text {, }}$

$$
C=.00245 \frac{\mathrm{I}^{3} \mathrm{~T}}{\mathrm{~b} \mathrm{t}^{3}} \mathrm{sec} .^{2} \text { per square inch }
$$

where

$I=$ Length of specimens in inches

$b, t=$ Dimensions of cross section of prism in inches, $t$ being in the direction in mien it is driven

an's

$\mathrm{T}=\mathrm{A}$ correction factor

The preceding formula could be used to give a value 
for Young's modulus, yet in the ASTM Specification 291-52T, "Method of Test for Resistance of Concrete Specimens to Rapid Freezing in Air and Thawing in Water," it is permissible to treat $C$ and $W$ as constants without introducing appreciable error.

Basically, a change in Young's modulus as a result of cycle freezing and thawing can be assumed to represent deterioration of a concrete specimen. It has been recommended that the initial fundamental transverse frequency of the specimen be assumed to represent a Young's modulus (relative 100 percent) to which other frequencies could be related by the formula

$$
P c=\frac{n_{c}^{2}}{n_{0}^{2}} \times 100
$$

where

$P c=$ Relative modulus of elasticity expressed as a percentage, after c cycles of freezing and thawing

$n_{0}=$ Fundamental transverse frequency at zero cycles of freezing and thawing

$\mathrm{n}_{\mathrm{c}}=$ Fundamental transverse frequency after $\mathrm{c}$ cycles of freezing and thawing

Thus, the relative moduli of elasticity were calculated for each specimen after each measurement of natural Irequency. The weights of the specimens were recorded throughout the experiment. Excessive pitting and pop-outs 
during the experiment, even at early stages, made weight analyses umeaningful. Iimonite was the main deleterious material in the gravel, and it caused most of the damage in this respect.

The durability factor was calculated by the formula

$$
\mathrm{DF}=\frac{\mathrm{PN}}{\mathrm{M}} \quad \text { (ASTMC 291-52T) }
$$

where

$$
\begin{aligned}
& D F= \\
P= & \text { Relative dynamic modulus of elasticity } \\
& \text { at } N \text { cycles, percent } \\
N= & \text { Number of cycles at which } P \text { reaches the } \\
& \text { specified minimum value for discontinuing } \\
& \text { the test or the specified number of cycles. } \\
& \text { at which the exposure is to be terminated, } \\
& \text { wichever is less }
\end{aligned}
$$

and

$\mathbb{N}^{2}=$ Specified number of cycles at which the exposure is to be terminated.

For the purpose of this research, the testing of any specimens was to be terminated at 300 freeze-thaw cycles, or when the relative modulus of elasticity dropped to 50 percent.

A curve showing the variation in the relative modulus of elasticity with the number of cycles of feezing and thawing was plotted for each specimen. 
Figure 8 shows the results obtained for each individual beam in mix I-A. Since these six beans were divided into three groups of similar specimens, only three legenas appear on the graph. The circied rigure at the end of each line indicates the number of the specimen. Figures 9, 10, 11, 12 and 13 show similar data for mixes I-B, I-C, II-A, II-B, and II-C, respectively.

Figure 14 is a plot of the average effect of freezing and thawing on the dynamic modulus of elasticity of similar specimens from mix I-A. It should be noted that each curve represents the average results from two similar specimens. Figures 15, 16, 17, 18 and 19 are nlots of similar data for similar specimens from I-B, I-C, II-A, II-B, and II-C, respectively.

Figure 20 summarized the results of series I. The values of the relative moduli of elasticity of each six similar specinens were averaged. Iikevise, average results from the six similar specimens of mix I in series I were computed and plotted on the same graph for purposes of comparison and evaluation. Fifure 21 sho:"s the results of series II in a similar manner. When a specimen was withdram from the experiment, its contribution to the average of the group was iropped; and the average ior the remaining similar specimens only were computed. To show this on the graphs, a vertical line was drawn throu h the approximate curve at the last average point taken before the withdrawal of the beams. This will explain 


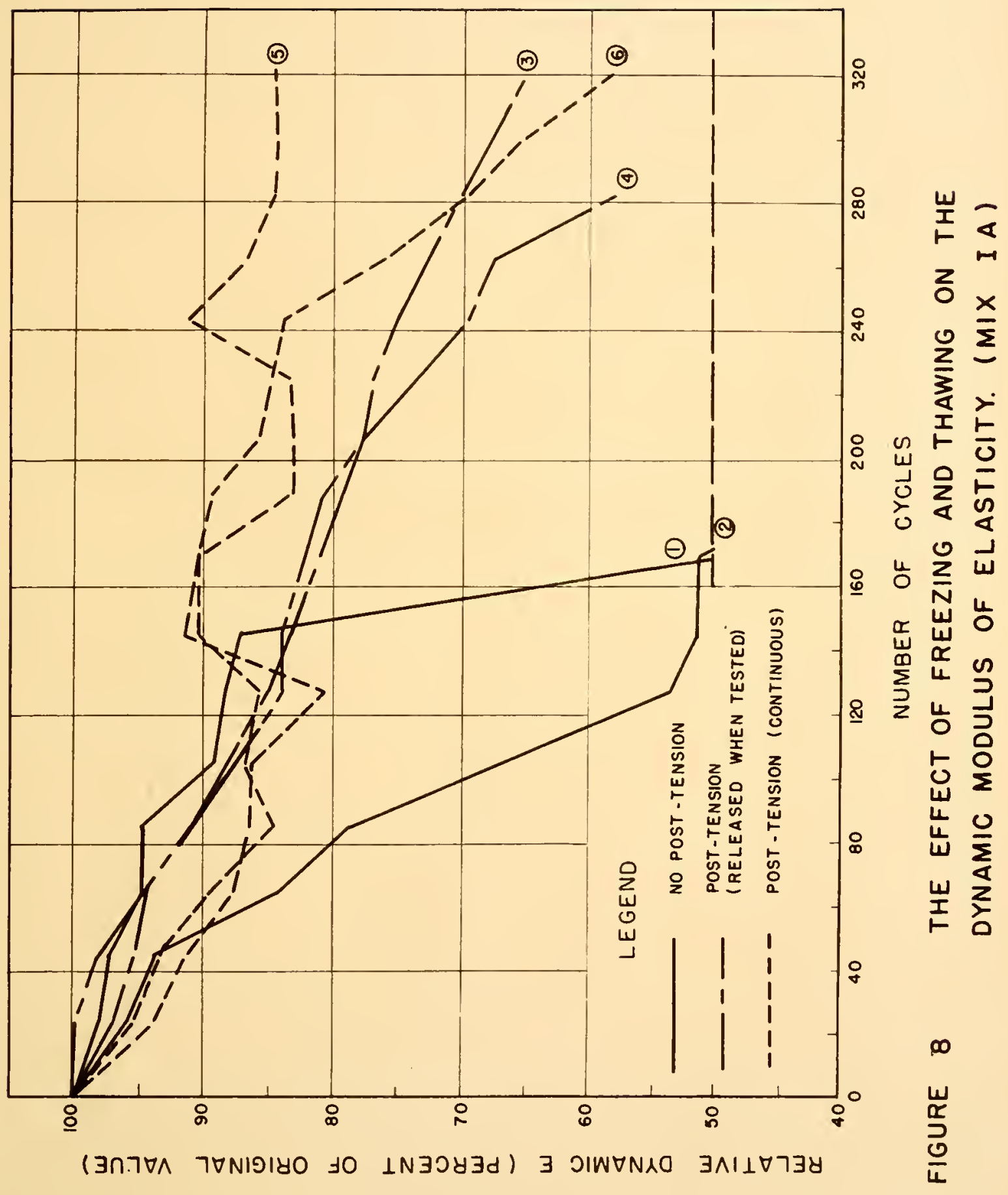




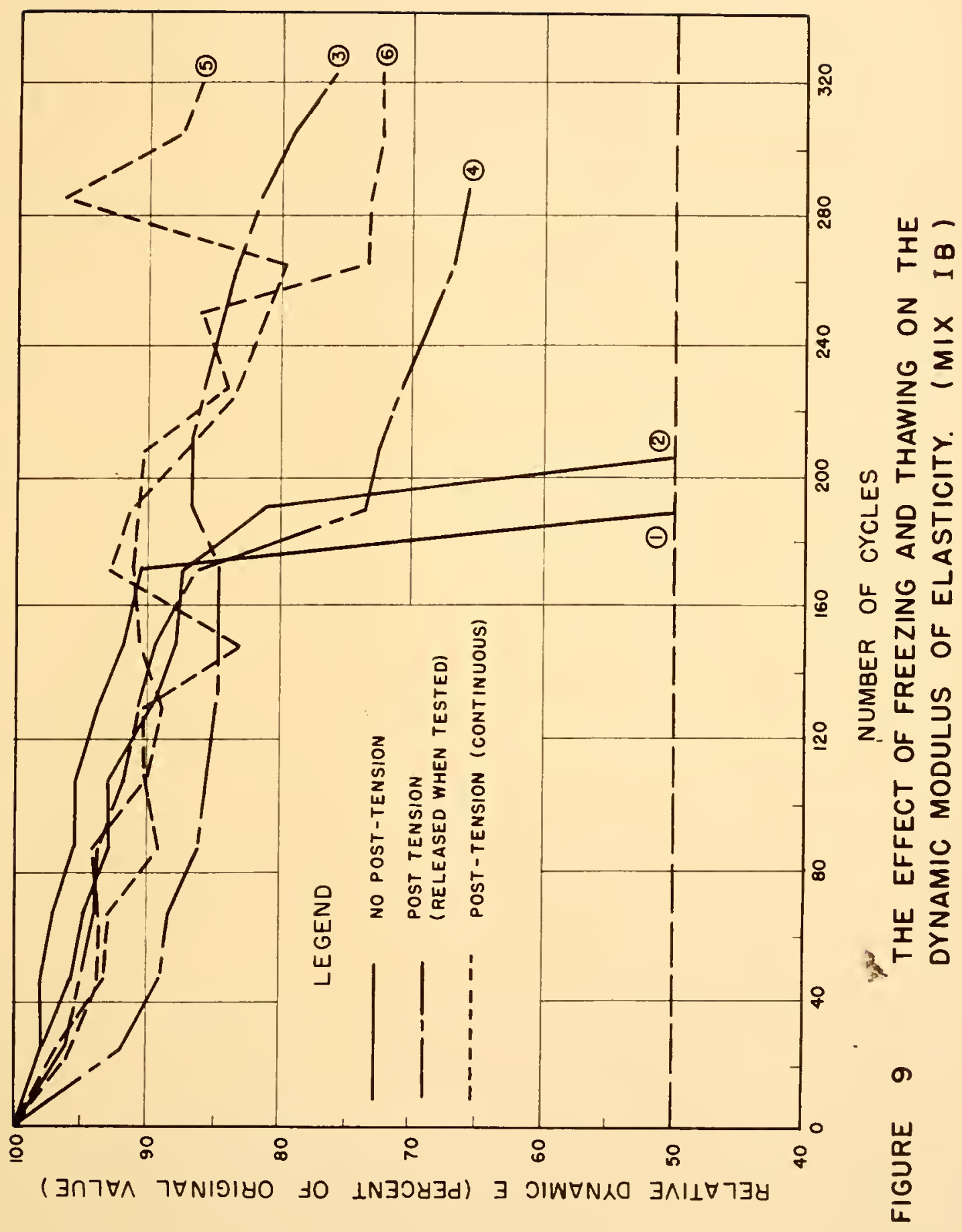




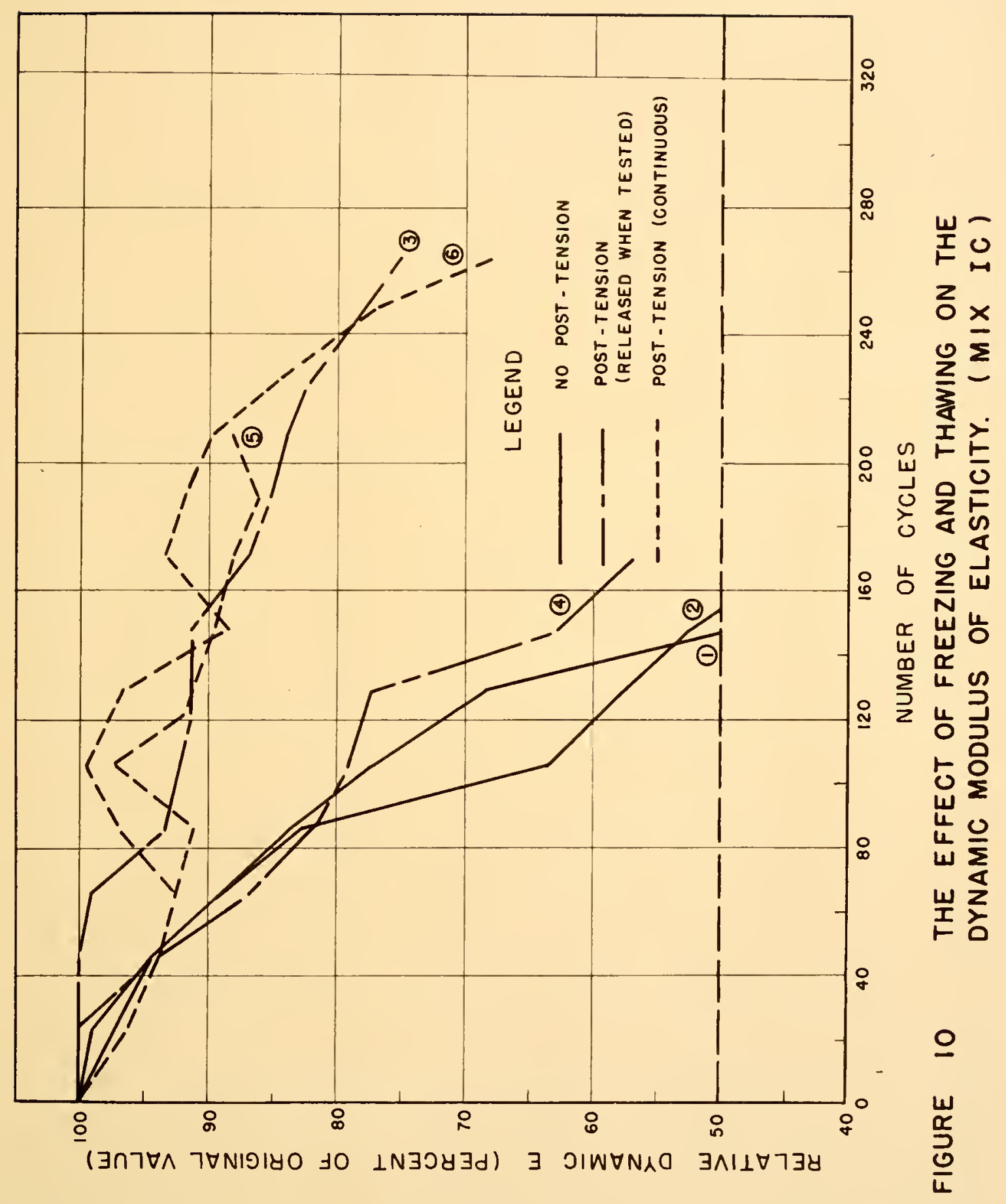




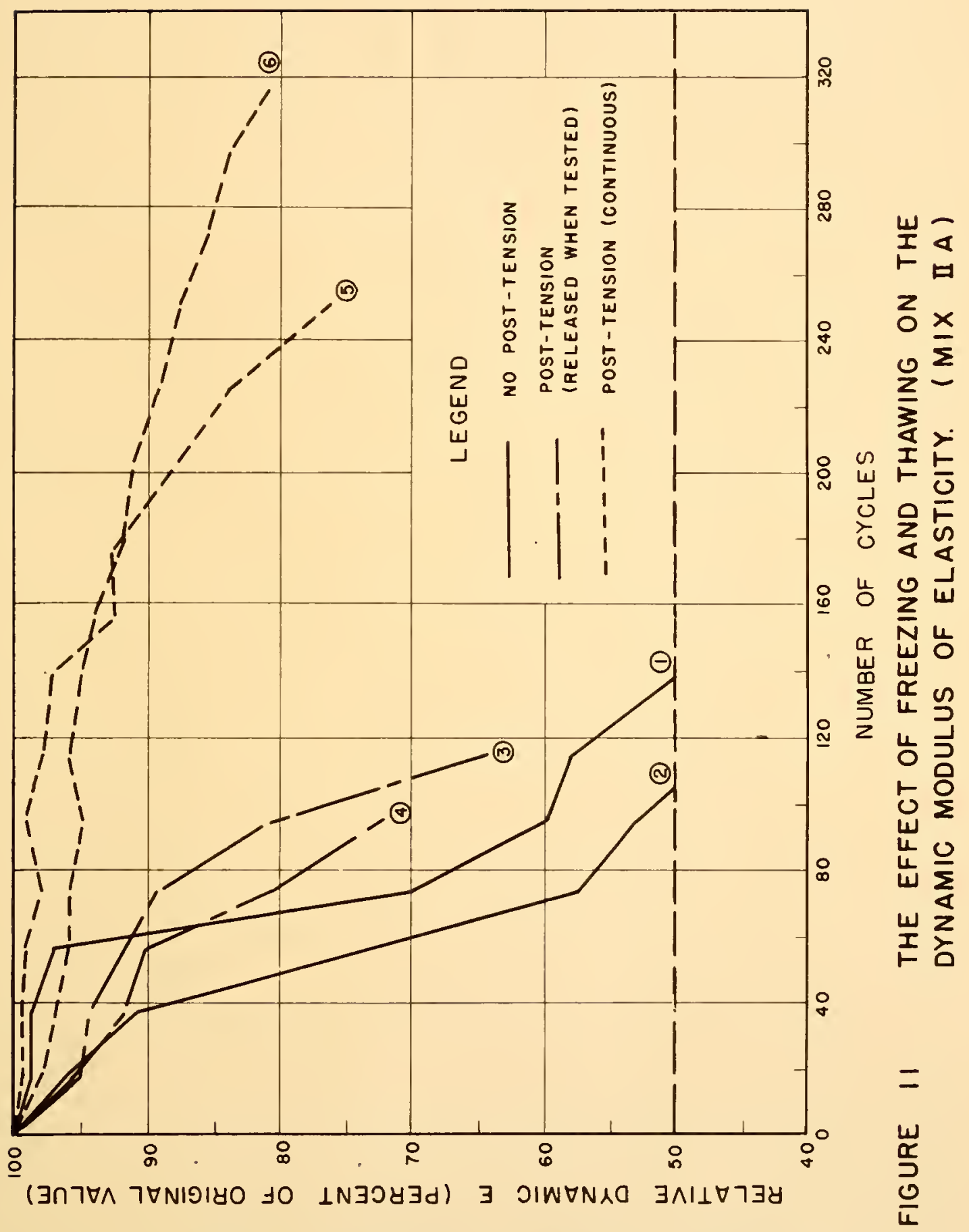




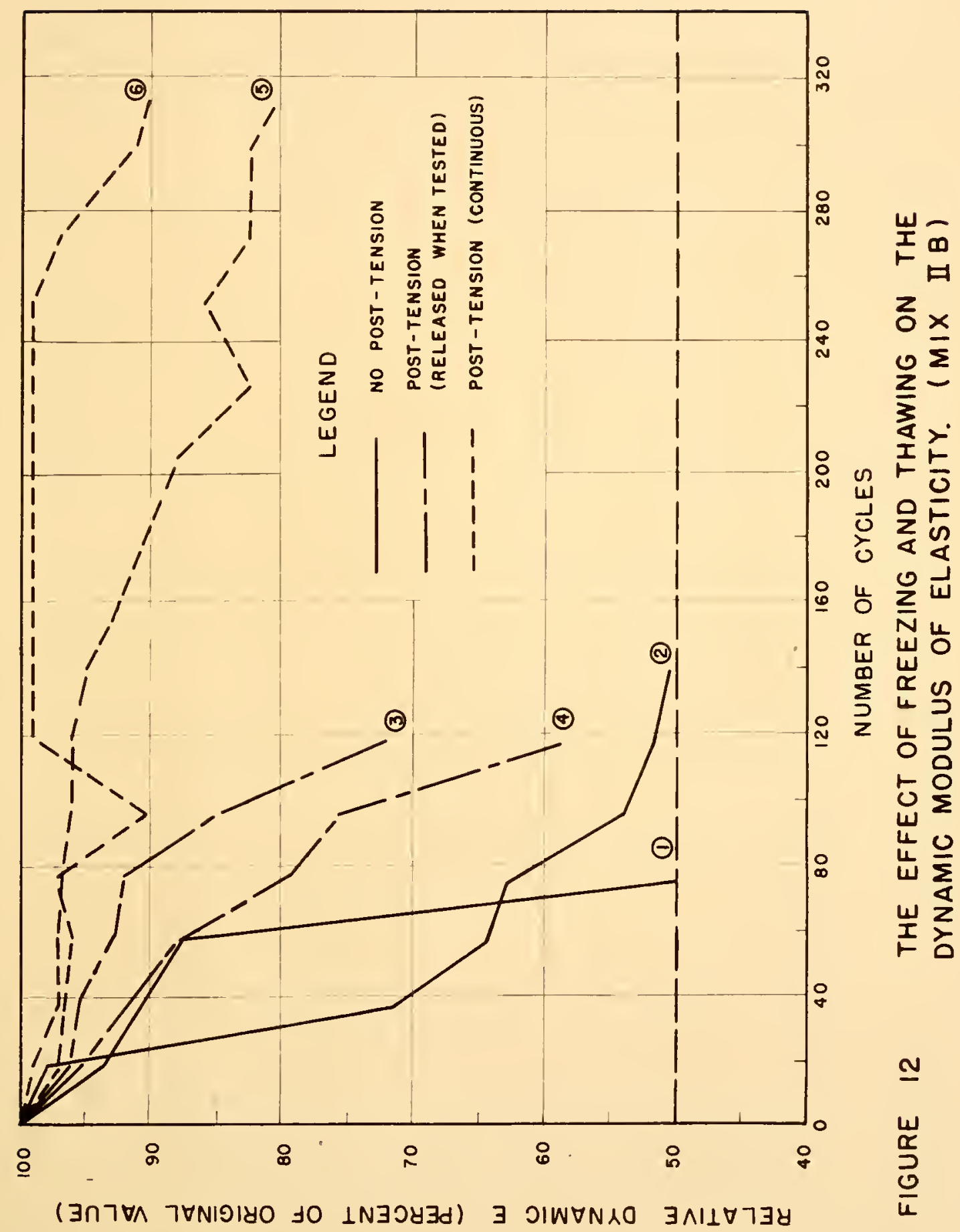




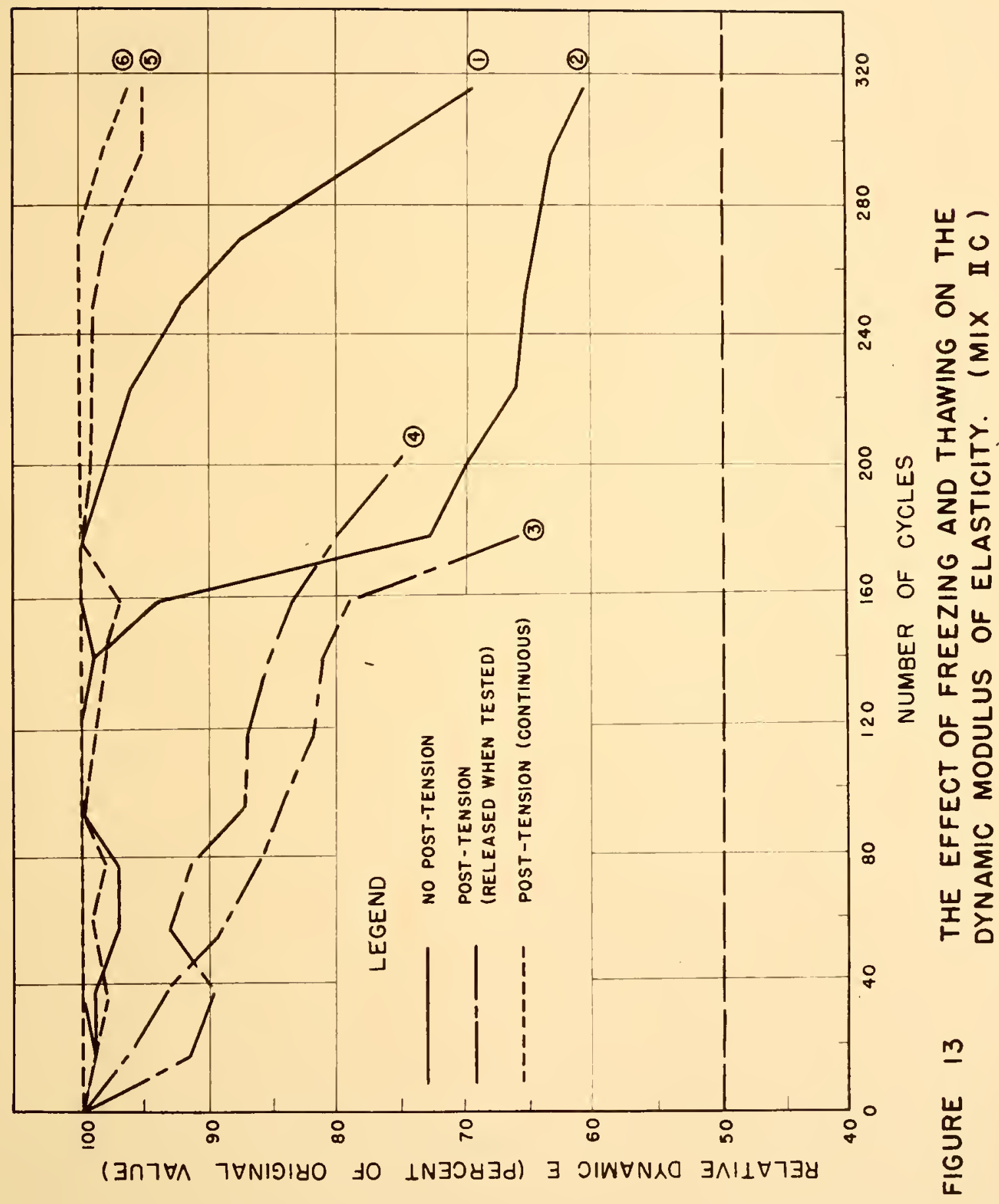




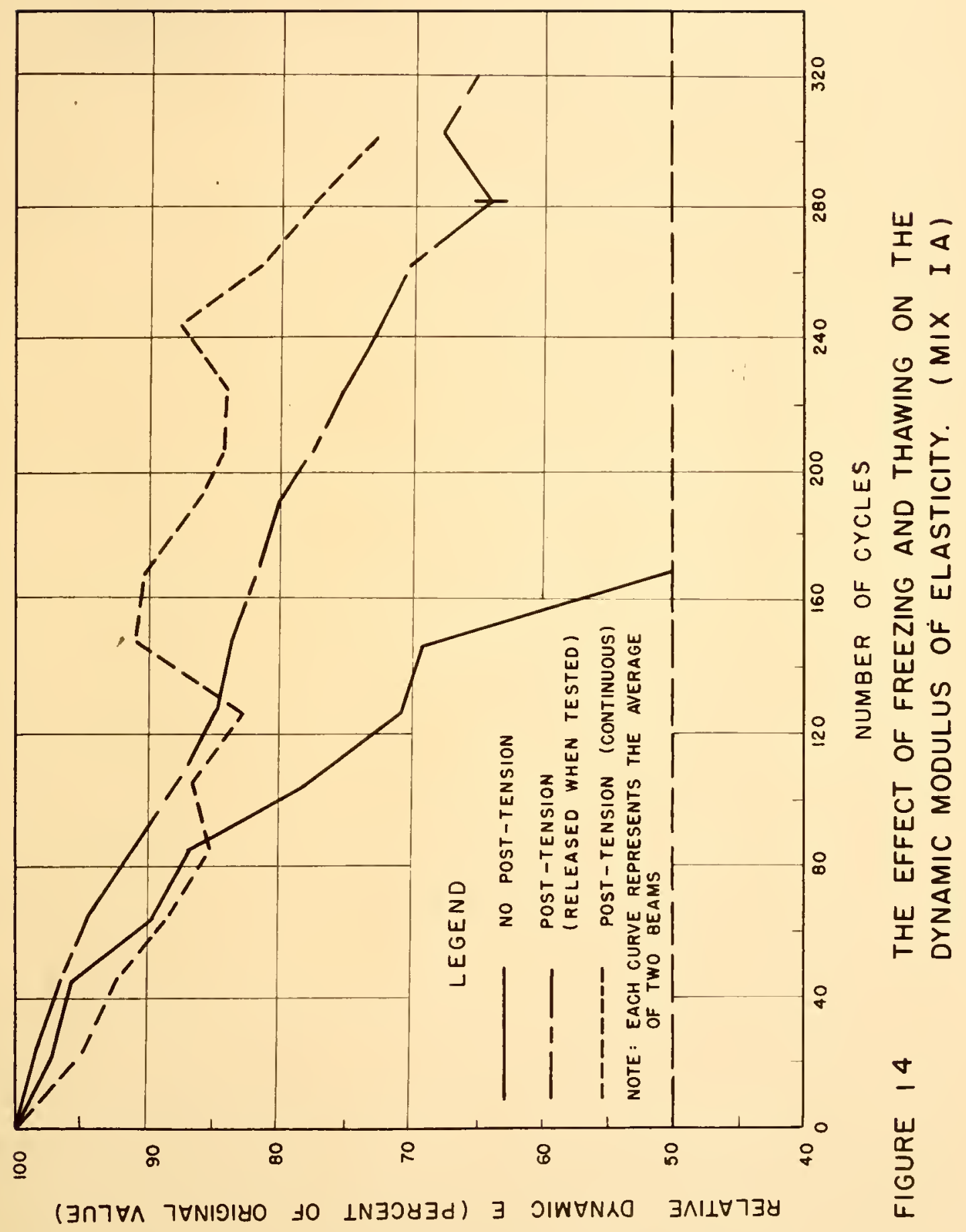




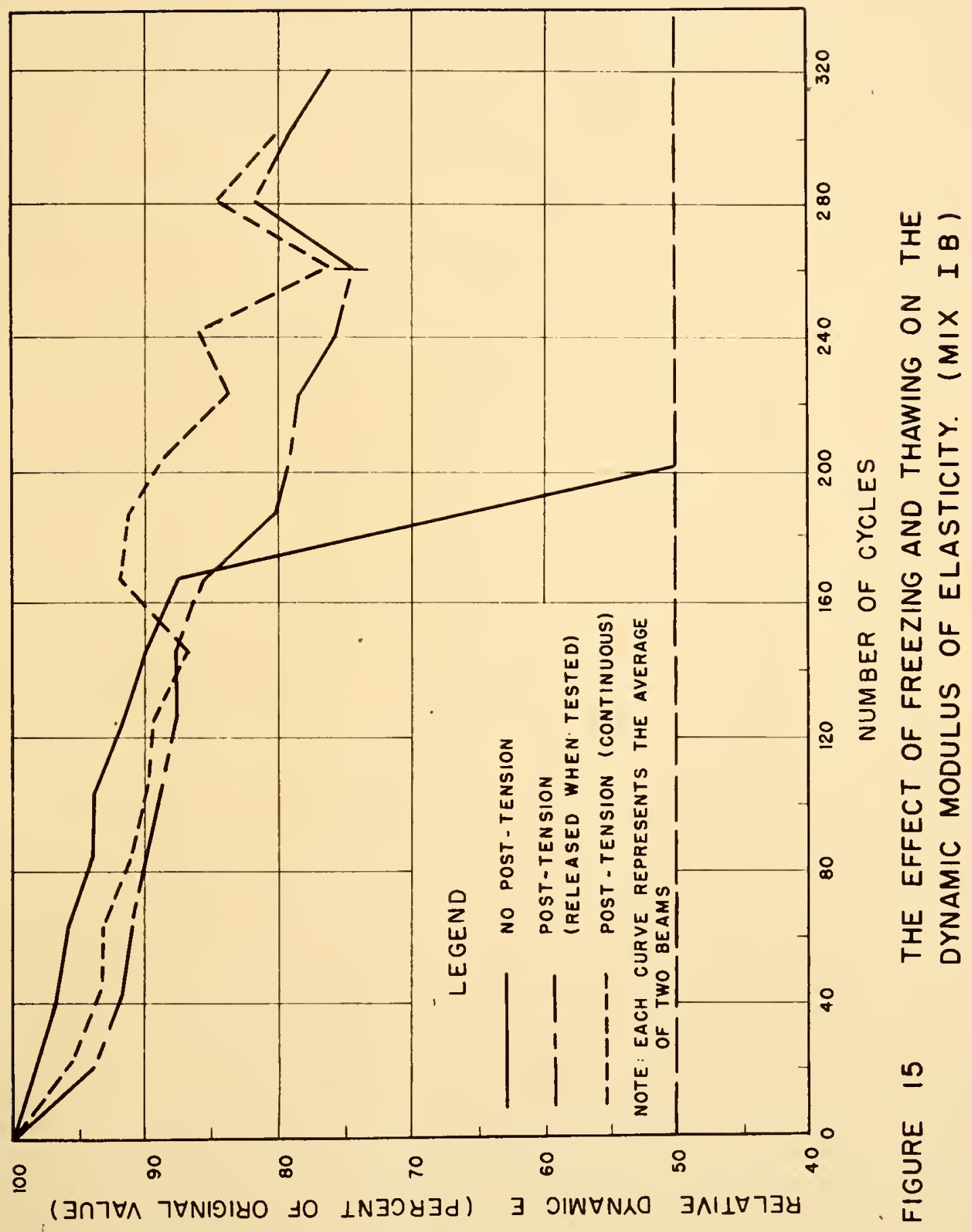




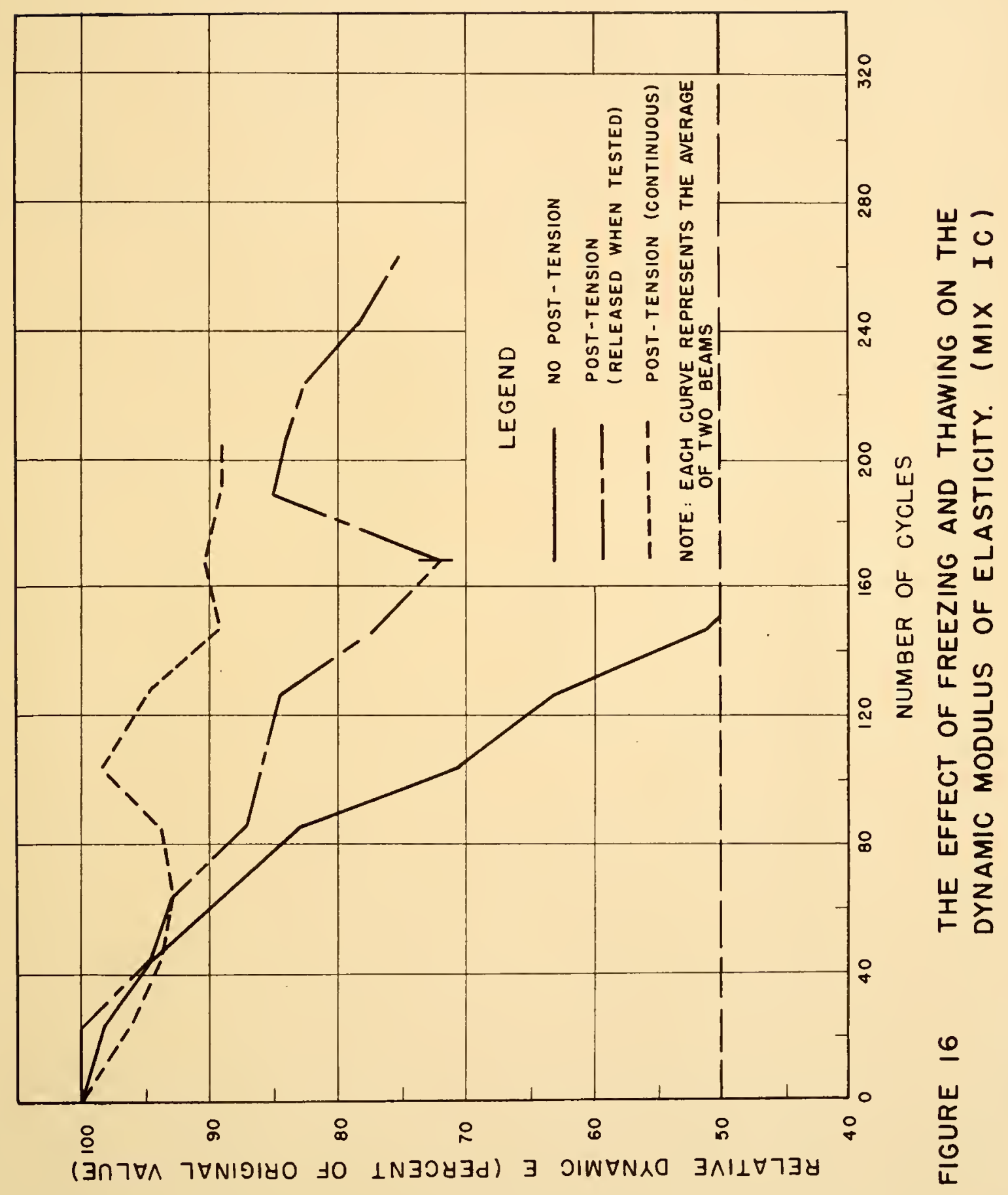




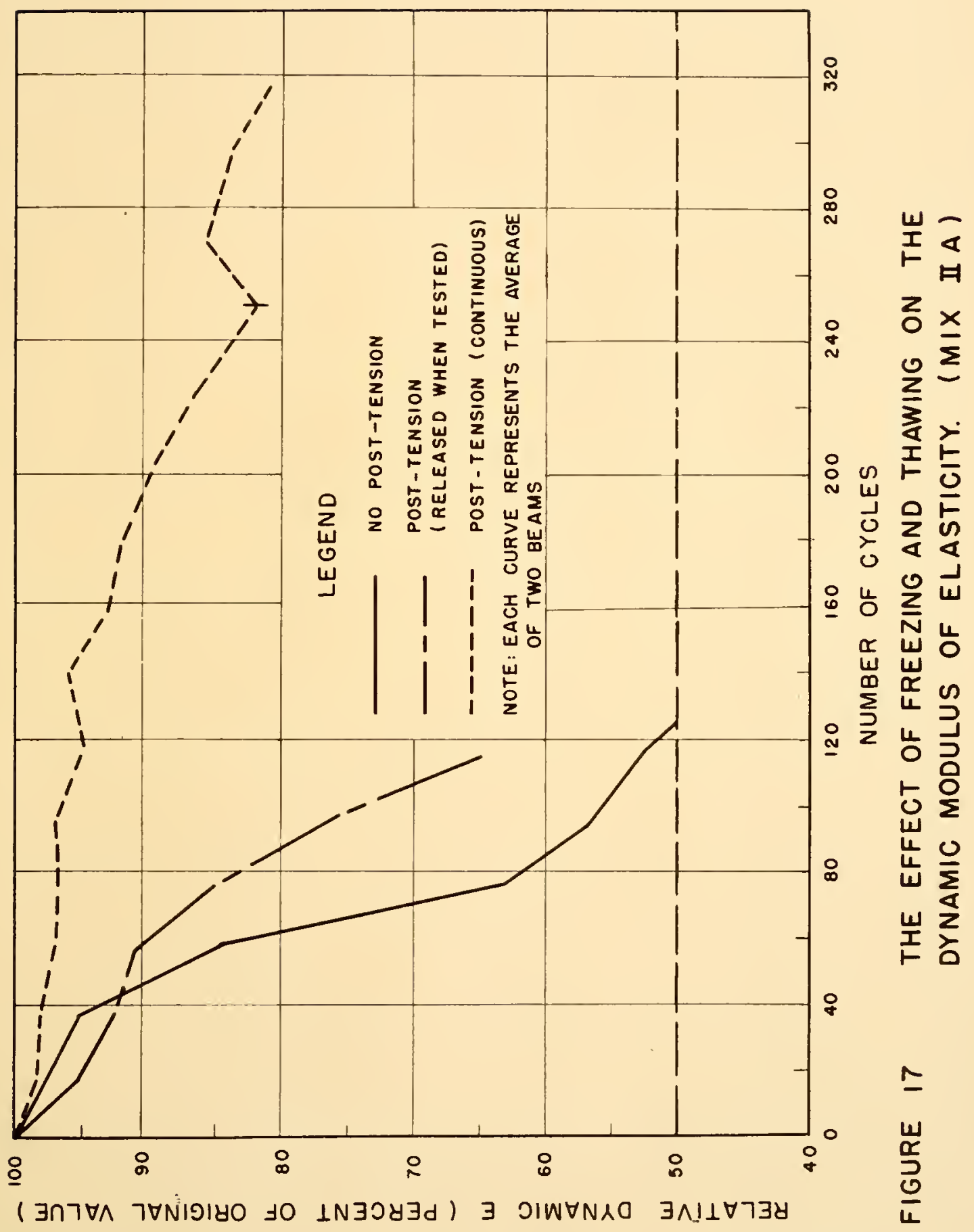




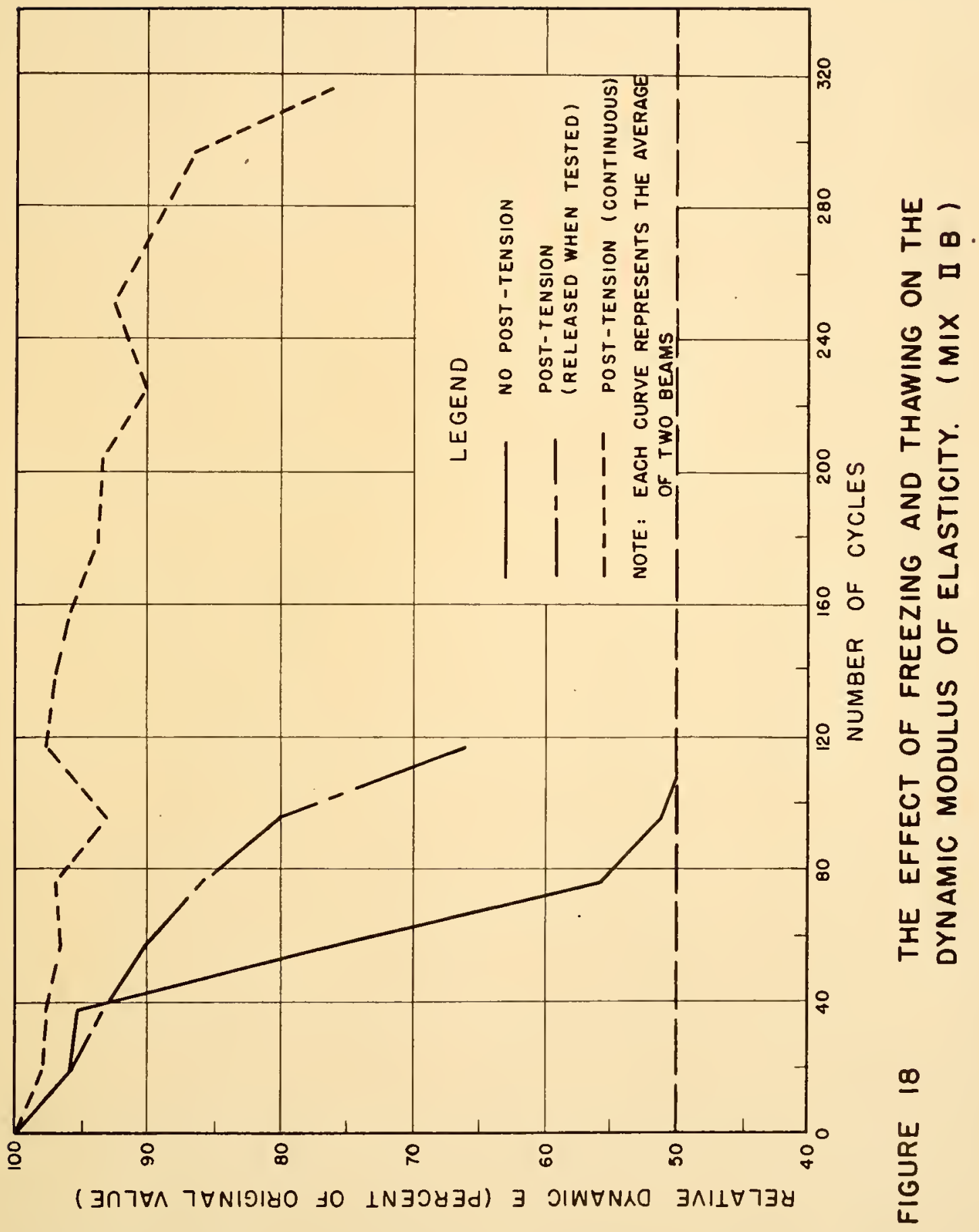




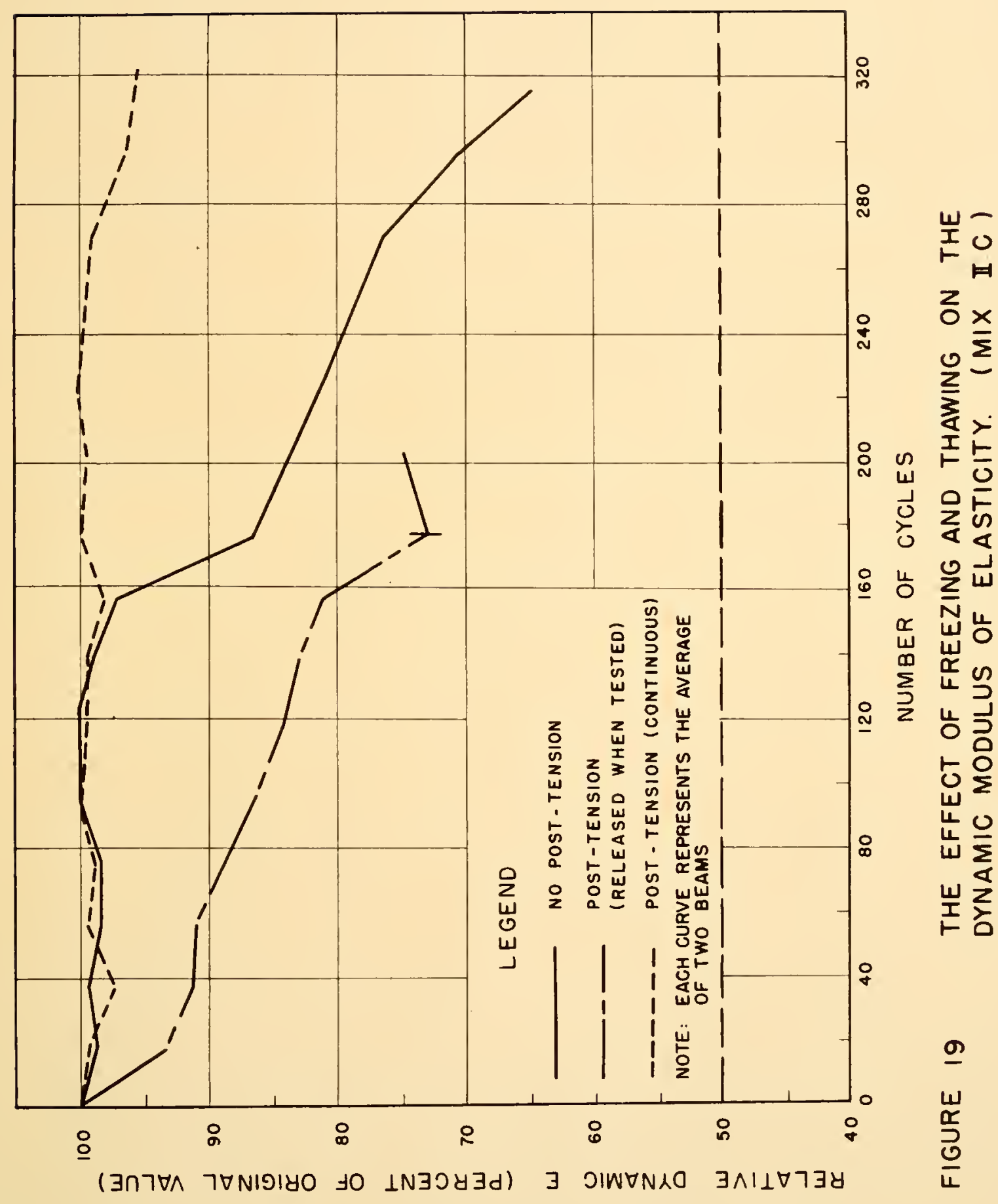




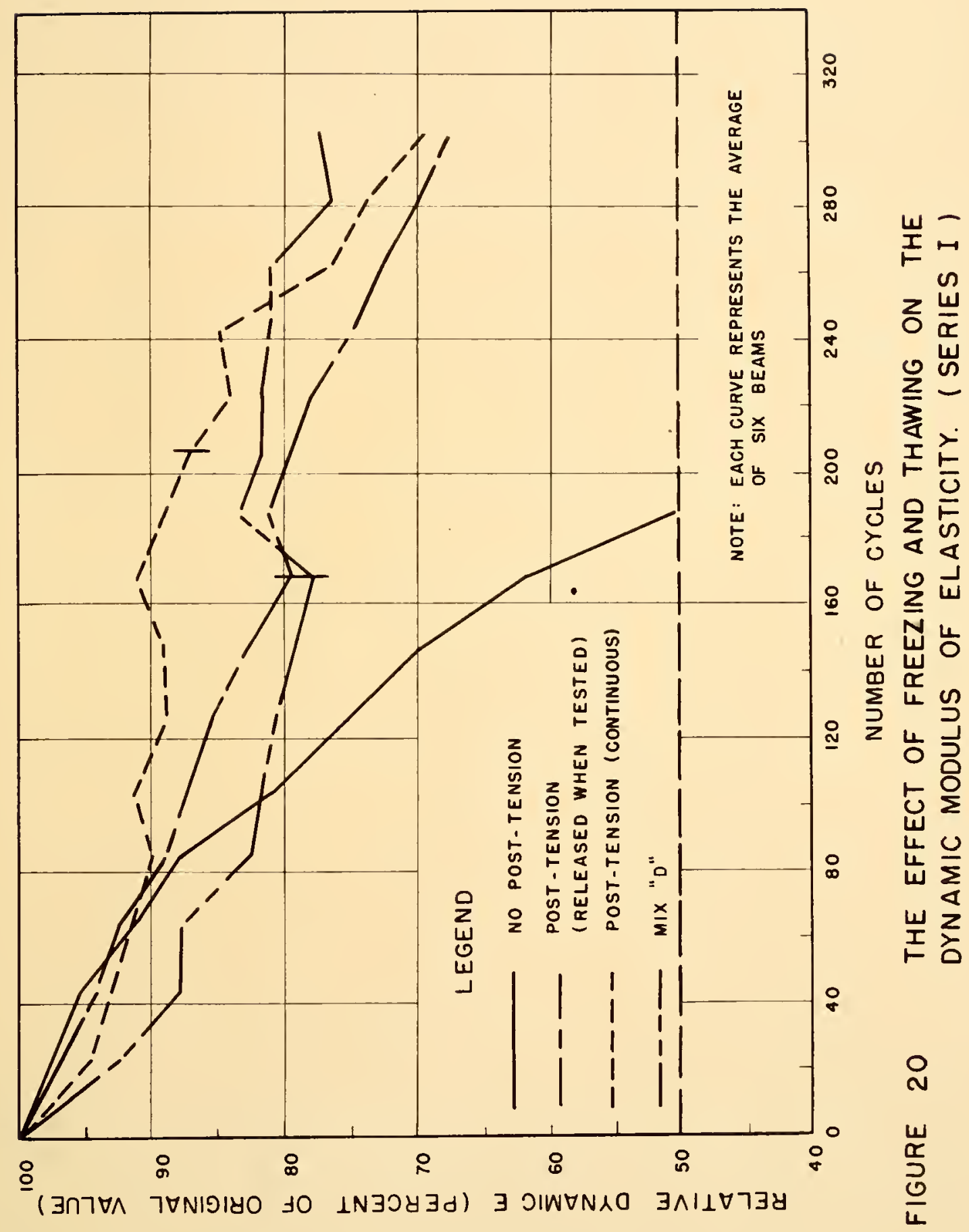




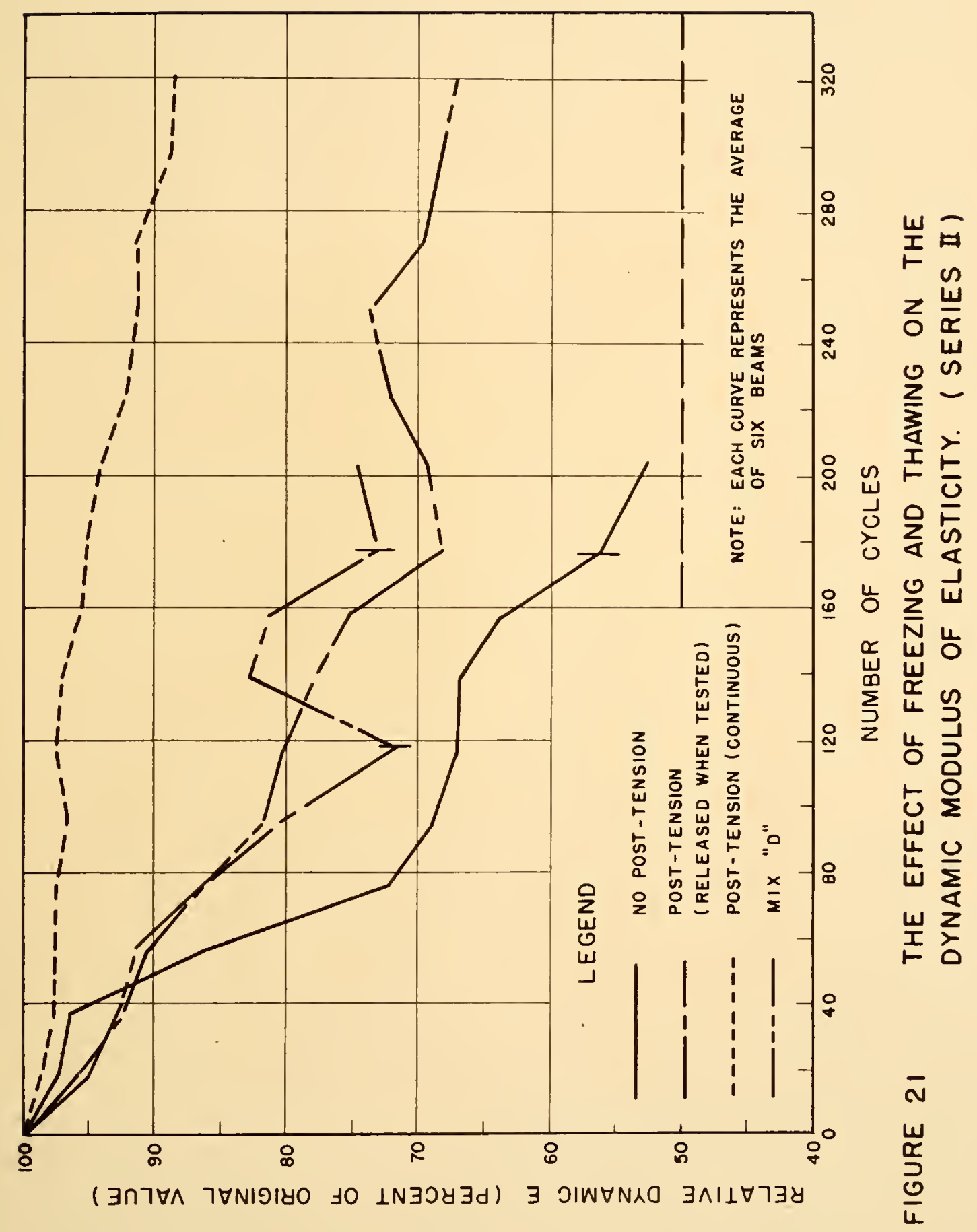


the sudden increases in some of the curves.

Table 6 shows the values of the durability factors for the individual beams of series $I$ at 300 cycles of freezing and thawing. The averare durability factor for each six similar beams was given.

Table 7 summarizes the results of sexies II in a similar manner.

\section{Tipes of Concrete Failure}

The decrease in the dynamic modulus of elasticity was measurable in all the specimens tested. In the case of beams numbered 3 and 4 of mixes $A, B$ and $C$, where the initial prestressing force was applied every time the beams were tested, this failure came at an early stage. In the heams numbered 5 and 6 , more freeze-thaw cycles were required to produce this failure. In the latter case, the initial prestressing force was applied before the beginning of the test and was maintained permanently throughout the whole study. As the experiment proceeded, creep in the concrete took place, and the initial prestressing force dropped significantly. A typical failure of the prestressed concrete beams is shown in Figure 22. In addition to the decrease in the dynarnic modulus of elasticity, Walker (12) listed three major classifications of deterioration in concrete due to unsound aggregates. These are (a) pitting and pop-outs, (b) D-line deterioration, and (c) map cracking. 
Table 6

DURABILITY FACTORS OF SERIES I BEANS

AT 300 CYCLPS

\begin{tabular}{|c|c|c|c|c|c|}
\hline \multirow{2}{*}{ MIX } & \multirow{2}{*}{ BEAM } & \multirow{2}{*}{$\begin{array}{l}3000 \text { PSI } \\
\text { PIAIN } \\
\text { CONCRETE }\end{array}$} & \multicolumn{3}{|c|}{5000 PSI CONCRETE } \\
\hline & & & $\begin{array}{l}\text { Plain } \\
\text { Concrete }\end{array}$ & $\begin{array}{l}\text { Prestressing } \\
\text { Force Peleased } \\
\text { During Testing }\end{array}$ & $\begin{array}{l}\text { Permanently } \\
\text { Prestressed } \\
\text { Concrete }\end{array}$ \\
\hline A & $\begin{array}{l}1 \\
2 \\
3 \\
4 \\
5 \\
6\end{array}$ & & $\begin{array}{l}27.5 \\
28.2\end{array}$ & $\begin{array}{l}67.6 \\
54.3\end{array}$ & $\begin{array}{l}84.6 \\
60.5\end{array}$ \\
\hline B & $\begin{array}{l}7 \\
2 \\
3 \\
4 \\
5 \\
6\end{array}$ & & $\begin{array}{l}31.2 \\
34.7\end{array}$ & $\begin{array}{l}79.1 \\
57.1\end{array}$ & $\begin{array}{l}87.9 \\
72.4\end{array}$ \\
\hline C & $\begin{array}{l}1 \\
2 \\
3 \\
4 \\
5 \\
6\end{array}$ & & $\begin{array}{l}25.7 \\
24.3\end{array}$ & $\begin{array}{l}65.8 \\
20.1\end{array}$ & $\begin{array}{l}60.5 \\
46.1\end{array}$ \\
\hline $\mathrm{D}$ & $\begin{array}{l}1 \\
2 \\
3 \\
4 \\
5 \\
6\end{array}$ & $\begin{array}{l}67.8 \\
14.1 \\
71.0 \\
86.0 \\
91.6 \\
69.5\end{array}$ & & & \\
\hline \multicolumn{2}{|c|}{ Average } & 66.7 & 28.6 & $57 \cdot 3$ & 68.7 \\
\hline
\end{tabular}


Table 7

DURA IIIMY FAGORS OY SIRI 3 II DEATS

AT 300 MLS

\begin{tabular}{|c|c|c|c|c|c|}
\hline \multirow{2}{*}{ IRIX } & \multirow{2}{*}{$B \neg A \cap:$} & \multirow{2}{*}{$\begin{array}{l}3000 \text { PSI } \\
\text { PIAINI } \\
\text { GOIST }\end{array}$} & \multicolumn{3}{|c|}{ 5000 PSI COICRETE } \\
\hline & & & $\begin{array}{l}\text { Plain } \\
\text { Concrete }\end{array}$ & $\begin{array}{l}\text { Prestressing } \\
\text { Porce Released } \\
\text { During Testing }\end{array}$ & $\begin{array}{l}\text { Permanently } \\
\text { Prestressed } \\
\text { Concrete }\end{array}$ \\
\hline A & $\begin{array}{l}1 \\
2 \\
3 \\
4 \\
5 \\
6\end{array}$ & & $\begin{array}{l}50.0 \\
18.0\end{array}$ & $\begin{array}{l}30.1 \\
28.0\end{array}$ & $\begin{array}{l}83.2 \\
82.0\end{array}$ \\
\hline B & $\begin{array}{l}1 \\
2 \\
3 \\
4 \\
5 \\
6\end{array}$ & & $\begin{array}{l}12.7 \\
23.3\end{array}$ & $\begin{array}{l}33.4 \\
28.4\end{array}$ & $\begin{array}{l}82.0 \\
91.3\end{array}$ \\
\hline C & $\begin{array}{l}1 \\
2 \\
3 \\
4 \\
5 \\
6\end{array}$ & & $\begin{array}{l}77.0 \\
63.3\end{array}$ & $\begin{array}{l}35.5 \\
37.3\end{array}$ & $\begin{array}{l}95.1 \\
98.0\end{array}$ \\
\hline$D$ & $\begin{array}{l}7 \\
2 \\
3 \\
4 \\
5 \\
6\end{array}$ & $\begin{array}{l}61.0 \\
84.0 \\
72.0 \\
55.4 \\
37.3 \\
68.0\end{array}$ & & & \\
\hline \multicolumn{2}{|c|}{ Averige } & 63.0 & 40.7 & 32.1 & 88.6 \\
\hline
\end{tabular}




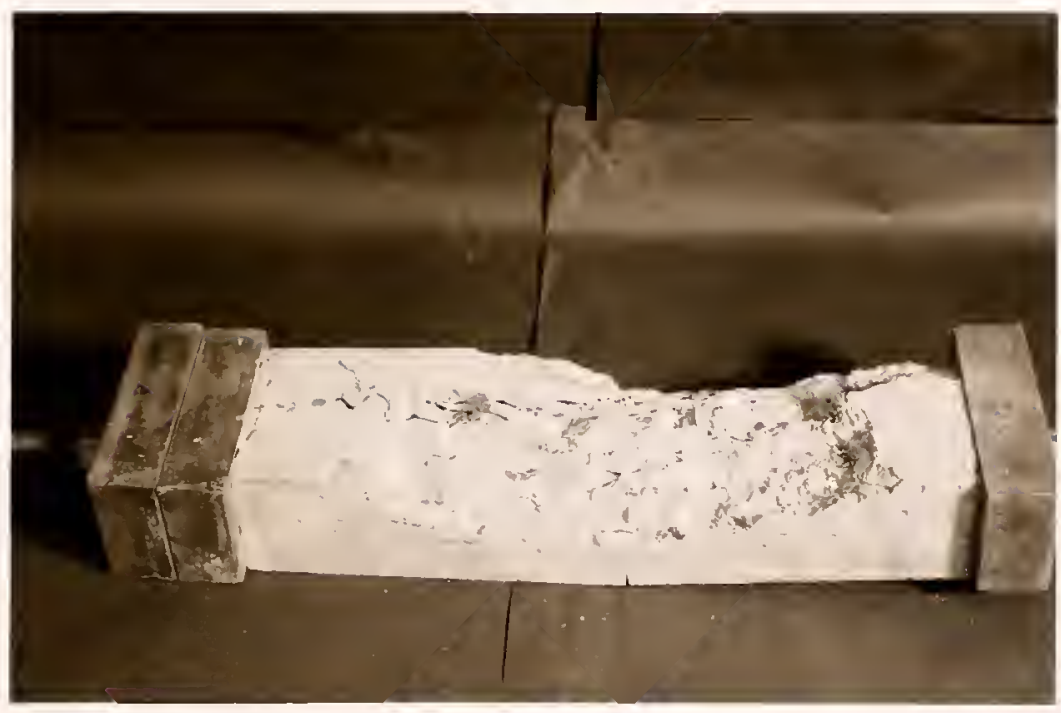

FIGURE 22 A TYPICAL FAILURE OF A POST-TENSIONED BEAM SPECIMEN C-3 SERIES I 
Pitting is the gradusil disintegration due to frost of deleterious pieces of aggregates near the surface of the specimen. Pop-outs take usually a conical shape with the apex being at the aggregate particle. These are caused by rapid dismption of a saturated piece of deleterious aggregate. Fitting and pop-outs were frequent during the experiment. They were mainly caused by the limonite particles in the aggregate.

D-line cracking is causei by the change in volume of coarse agregate particles breaking the bond with the mortar matrix. D-lines first appear as fine cracks along the free edges of the specimen. These were noted on some of the specimens.

Ifap cracking is a form of disintegration in which random cracks levelop over the entire surface. This kind of failure was not.found in this study.

Figure 23 shows samples of pitting, pop-outs, and D-Iine cracking as indicated.

\section{Discission 오 Results}

In the analysis of the results of any freezing and thawing test, cetain facts should be kept in mind:

1. No generally accepted freezing end thawing test has been developed un to this time. The ASTH specifications list four tentative methods for such tests.

2. The freezing and thawing test cannot establish quantitative information to determine the length of actual 


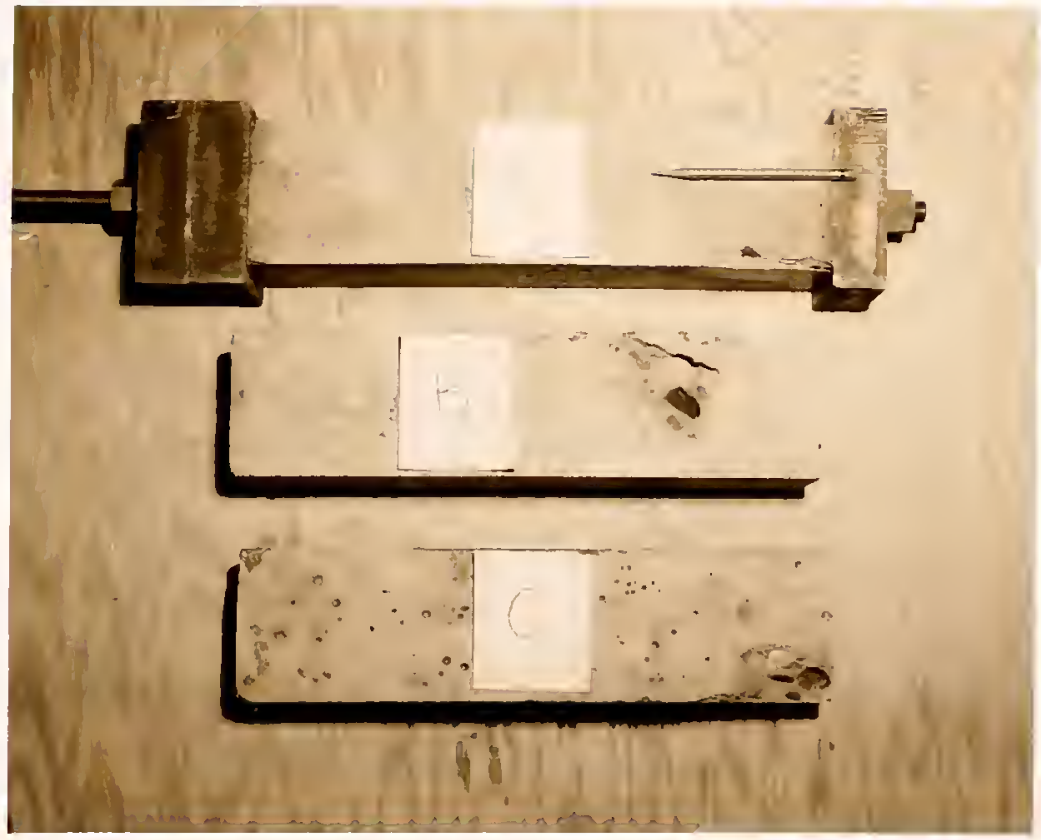

FIGURE 23 THREE TYPES OF FAILURE OF CONCRETE CAUSED BY DEIETERIOUS MATERIAI
A D-Line Deterioration After 15 Freeze-Thaw Cycles
B Pop-out After 300 Freeze-Thaw Cycles
C Pitting After 300 Freeze-Thaw Cycles 
performince of concrete in the field. The test is expected to give a general idea about the qualitative behavior of the concrete exposed to the natural weathering conditions.

3. At best, the results to be obtained from a freezing and thawing test are comparative data on durability of the test specimens.

4. The accelerated freezing and thawing tests that are performed in the laboratory are general ${ }^{2} y$ considered to be very severe tests.

5. The vacuum saturation of the aggregate makes it particularly vulnerable to attack by fresing and thawing. The aggregates that are to be used in concrete in the field are never vecuum situr ted.

The freving and thaxing test specitied by the ASTn are meant to be performed on homogeneous beams of concrete. There is no test specified to study the efects of rreezing and thewing on reinforced or prestressed concrete. The test used for plain concrete specimens was alopted in this research. The steel bars that were inserted at the center of the beams aid not influence the results obtained in this study for the following reasons:

1. The steel bars were used on all beams tested. Thus, the comparative results obtained are consilered vilid. 2. No bond was developed between the steel and the concrete. A s:mple beam was tested for its fundamental frequency with the bar in its center, ana then the same beam 
was tested acain with the bar completely removed. The fundonental frequencies measured in both cases vere identical. This check vas repeated frequently during the varlous stages of the experiment and the same results wore obtained in overy checl. This means that the fundanental frequency of the concrete was not affected by the unstressed steel bar.

Bearns numbered 5 and 6 of mires $A, B$ and $C$ of both series vere tested for the fundanental frecuency in a posttensioned condition. The loading arrangement adopted consisted of a non-bonded steel bar placect axia.lly in the center of the beam and post-tonsloned in the standard manner, distribution plates being used at the ends of the beam to transmit the load to the concrete. Steel nuts on the outer side of each end plate maintained the posttensioning force. This arrazgement provided a selfcontalned system which was tested dynamically in a manner similar to that used for the unstressed concrete. In this case the fundariental frequency of the stressed system, for any beam, was about half the value obtained for the same bean with end plates removed. Niout $5 \%$ of the reduction was due to the stross, the renaining reduction was due to the mass of the end plates and nuts. A detalled theoretical analysis Elven by Elvery and Furst (13) presented some equations which show this effect of end plates and stress on the fundanental frequency of the specimen. Then these beams were subjected to the repeated cycles of freezins and thawing, the fundamental frequency of the syster dropped. This 
indicated the deterioration that occurred in the posttensioned beams. This deterioration occurred in the concrete and the post-tensioning of the concrete did influence the rate and the nature of the deterioration as will be show later.

The results of the experiment in all the mixes designated by IA, IB, IC, IIA and IIB show that beams numbered 3 and 4 were more durable than beams numbered 1 and 2 . This indicates that post-tensioned concrete, with the stress released every time the test for fundamental frequency was conducted, showed better resistance to freezing and thawing than unstressed concrete made of the same mix. These results may be observed by studying the graphs in Figures 8 to 12,14 to 18, and 20 as well as Tables 6 and 7.

In mix IIC this pattern was reversed as shown in Figures 13 and 19. The usual behavior for beams numbered 1 and 2 , in all the rich mixes, was for the relative modulus of elasticity to show a slight decrease early in the experiment. After a number of cycles, which varied from mix to mix, the relative modulus of elasticity would drop suddenly. However, in mix IIC the drop came after about 300 cycles. At the same time the deterioration of beams numbered 3 and 4 was gradual throughout the experiment. This also explains the fact that the average durability factor for plain concrete was higher than the average 
durability factor for the post-tensioned concrete in series II as show in Table 7. In the averages of the dynamic modulus of elasticity plotted in Figure 2l, for the groups of six similar beams, the efect of mix IIC is not apparent.

The results of all mixes designated $A, B$ and $C$ in both series show that the continuously post-tensioned beams, which were numbered 5 and 6 , were considerably more durable than beams numbered 3 and 4 in which the posttension was released for modulus measurements and were also better than the unstressed beams numbered 1 and 2 . Elvery and Furst (13) reported a reduction of about five percent in the dynamic modulus of elasticity when the concrete was subjected to a repeated cycle of compressive loading and unloading. This is in complete agreement with the results found in the study.

To summarize, one can definitely conclude that the post-tensioned concrete showed better resistance to freezing and thawing than the unstressed concrete of the same mix. One of the main objectives of this research was to compare the erfect of freezing and thawing on post-tensioned concrete made of a rich mix and ordinary concrete made of a leaner mix. Figures 20 and 21 show the summary of results for series I and II. It is clesr that the posttensione concrete specimens were more durable than the unstressed, leaner-mix concrete specimens designated as $\operatorname{mix} \mathrm{D}$. 
It is clear also that the mix specimens were more durable than unstressed specimens of the richer mixes $A, B$ and $C$. This result was the main reason for testing series II which confirmed the initial result of series I. These same observations may be made by a study of the average durability factors in Tables 6 and 7 . It is believed that the data obtined in this study is too limited to draw a general conclusion in this respect; however, within the range of variables in this experiment, it can be said that the richer mix siowed a higher rate of deterioration than the leaner mix. This result is consistent with Fo:ers' hypothesis (8) and is in complete agreement with the results obtained by Bartel (2) and by Walker and Bloem (5). 


\section{CONCLUSIONS}

Based on the results obtained and within the Iimitations of the variables studied in this experiment. the following conclusions are aram:

1. The post-tensioning of concrete improves Its effective durability against cyclic freeging and thawing.

2. Continuously post-tensioned concrete, having a. minimun ultimete strength of 5000 psi after 28 days 1s effectively nore durable then unstressed concrete having minimun ultimate strength of 3000 psi after 28 doys.

3. Continuously stressed concrete is effectively more durable than intermittently stress-releesed cancrete of the same mix; furthemore, In four out of s1x cases, the latter is apparently more duroble than unstressed concrete of the same mix.

4. Ordinary concrete beams made from a rich $\mathrm{mix}$ are less durable than ordinary concrete beans made of a leaner mix. 


\section{BIBLIOGRAPHY}

1. Lewis, D. W., and loods, K. B., "Research as Related to Aggregate Specifications," Proceedings, 35th Annual Road School Extension Series No. 69 Purdue University, 1949, pp. 155-173.

2. Bartel, F. F., "Effect of Air Entrainment on Resistance to Freezing and Thawing of Concrete Made with Questionable Aggregates," Circular 31, National Sand and Gravel Association, March, 1949.

3. Pendley, I. C., "The Effect of Restraint on the Durability of Concrete Aggregates," Thesis, submitted to Purdue University in particl fulfillment of the requirements for the degree of Master of Science in Civil Engineering, June, 1949.

4. Higgs, J. G., "Influence of Fine Aggregates on Concrete and Mortar Durability," Thesis, submitted to Purdue University in partial fulfillment of the requirements for the degree of Master of Science in Civil Engineering, February, 1950.

5. Walker, S., and Bloem, D. I., "Study of Sands in Concrete Subjected to Freezing and Thawing," Circular 34, National Sand anò Gravel Association, August, 1949.

6. Jackson, F. H., "Resistance of Concrete to Frost Action as Affected by the Water-Cement Ratio," Proceeding, Highway Research Board, Vol. II, Part I, p. 227 (193I). 
7. Hansen, I. O., "Weathering Tests on Concrete," Proceedings, Highway Research Board, Vol. 14, p. 303 (1934).

8. Powers, T. C., "A Working Hypothesis for Further Studies of Frost Resistance of Concrete," Froceedings, American Concrete Institute, Vol. 4l, p. 245 (1945).

9. Goldbeck, A. T., and Gray, J. E., "A Method of Proportioning Concrete for Strength, Workability, and Durability," Bulletin No. 11, National Crushed Stone Association, 1953.

10. "Recommended Practice for Selecting Proportions for Concrete," Proceedings, American Concrete Institute, Vol. 50, p. 105 (1954).

11. "Tent tive Recommendations for Prestressed Concrete," ACI-ASCE Joint Committee 323, Proceedings, Journil of the American Concrete Institute, Vol. 54, Jan., 1958.

12. Walker, R. D., "The Effect of Crushed Stone and Heavy Media Separation on the Durability of Concrete Made with Indiana Gravel," Thesis, submitted to Purdue University in Partial Fulfillment of the Requirements for the degree of Master of Science in Civil Engineering, June, 1955.

13. Elvery, R. H., and Furst, M., "The Effect of Compressive Stress on the Dynamic Modulus of Concrete," Magazine of Concrete Research, Vol. 9, No. 27, p. 145, November, 1957. 

